$\begin{array}{lllllllllllllllllllllllll}\text { I } & D & A & H & 0 & & N & A & T & \text { I } & 0 & N & A & L & L & A & B & 0 & R & A & T & 0 & R & Y\end{array}$

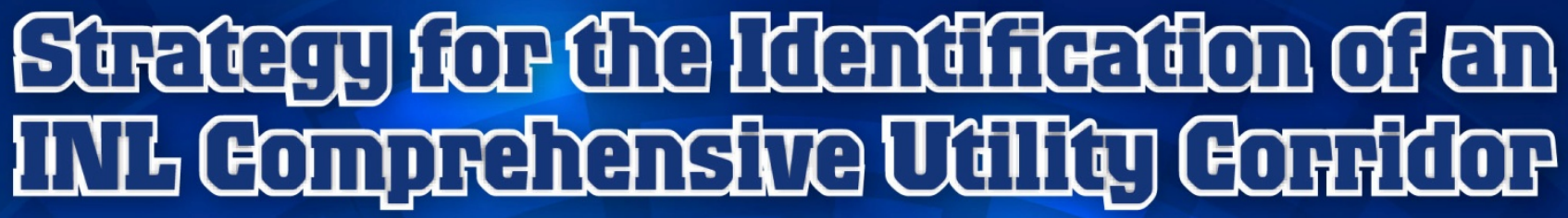

MAY 2011

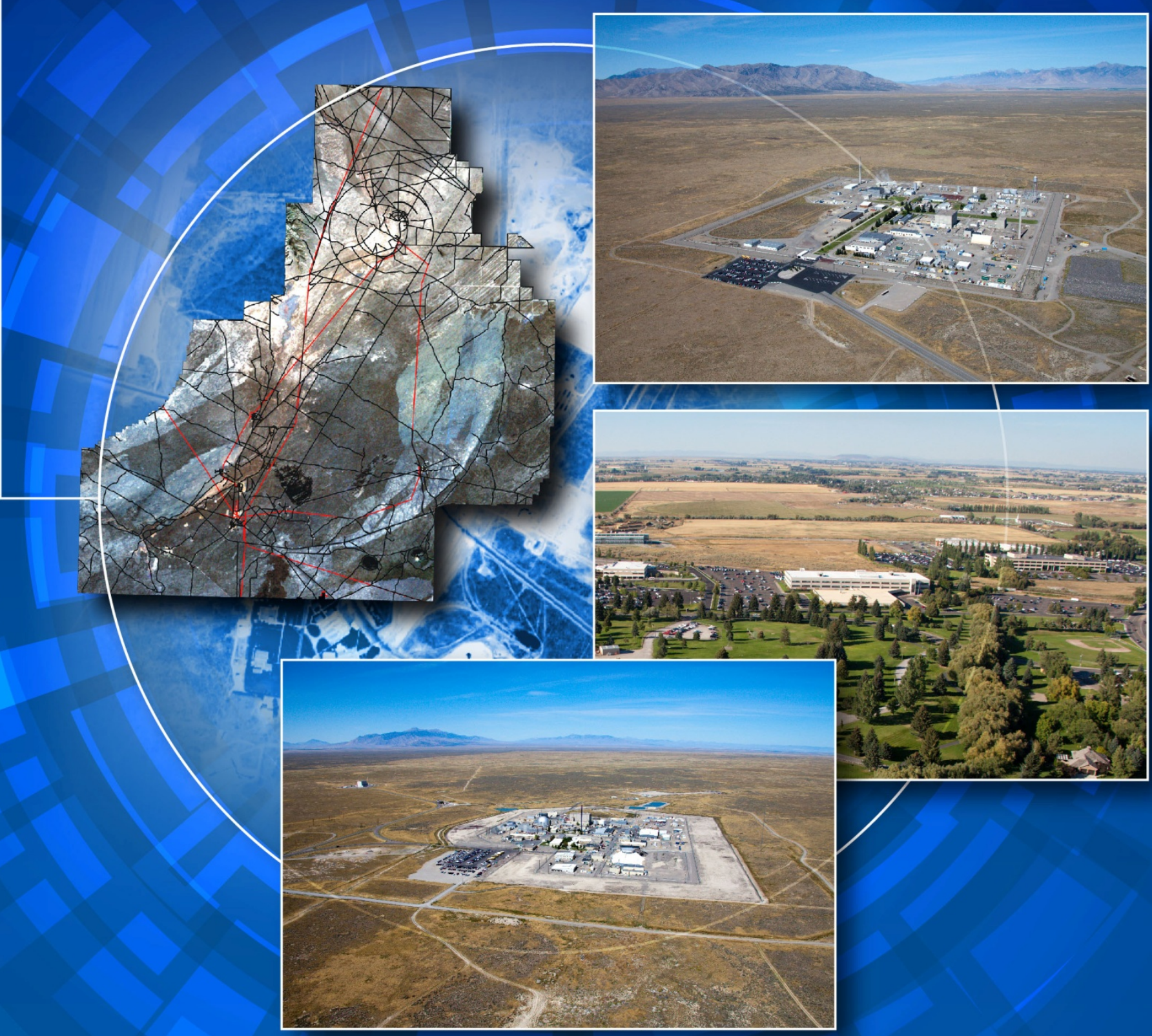

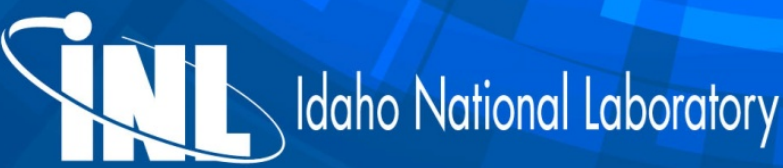




\section{DISCLAIMER}

This information was prepared as an account of work sponsored by an agency of the U.S. government. Neither the U.S. government nor any agency thereof, nor any of their employees, makes any warranty, expressed or implied, or assumes any legal liability or responsibility for the accuracy, completeness, or usefulness, of any information, apparatus, product, or process disclosed, or represents that its use would not infringe privately owned rights. References herein to any specific commercial product, process, or service by trade name, trade mark, manufacturer, or otherwise, does not necessarily constitute or imply its endorsement, recommendation, or favoring by the U.S. government or any agency thereof. The views and opinions of authors expressed herein do not necessarily state or reflect those of the U.S. government or any agency thereof. 


\title{
Strategy for the Identification of an INL Comprehensive Utility Corridor
}

\author{
John Reisenauer
}

May 2011

Idaho National Laboratory Idaho Falls, Idaho 83415

http://www.inl.gov

Prepared for the

U.S. Department of Energy

Office of Nuclear Energy

Under DOE Idaho Operations Office

Contract DE-AC07-05ID14517 



\section{EXECUTIVE SUMMARY}

Enclosed under cover is a report documenting the strategy developed for evaluating requests for utility corridors across the Idaho National Laboratory (INL). Interest has been expressed in crossing INL with a comprehensive utility corridor (CUC); however, INL mission land-use needs were not documented nor were potential corridor routes identified and evaluated for impacts to INL missions. As a result, the U.S. Department of Energy (DOE) requested that INL develop this CUC strategy. DOE "has a responsibility to ensure the land is used primarily in support of INL missions while protecting the environmental, ecological, and cultural aspects of the site," and this document details those requirements.

The objective of the CUC Project is to identify CUC options for consideration by mapping (with the geographic information system) current and future mission land-use needs, along with other known factors (e.g., historical sites, protected areas, roads, power lines and rights of way).

The process for developing a CUC strategy consists of the following four basic elements that, once developed, will contain critical site information that must be evaluated to establish the strategy:

1. Development of a base layer INL site map that geospatially references all stationary geographical features on INL and sitewide information.

2. Identification of current and future mission land-use needs; this is a 30-year look into the future for INL programs. These land-use needs were captured by geospatially referencing them on geographic information system-based site maps.

3. Identification of restricted and potential constraint areas, including wells, contaminated areas, unexploded ordinance areas, firing ranges, cultural areas, ecological areas, easements, hunting areas, and grazing areas.

4. Development of state highway and power line rights of way and easements; locations were identified across the site.

The area with the least impact on INL missions is around the perimeter of the INL Site. Option 1 identifies this perimeter; however, it does not mean the entire perimeter is viable. Many places along the perimeter corridor cannot be used or are not economically viable.

Option 2 identifies areas along existing highways that could be used as potential corridors. Discussions would have to take place with the State of Idaho to use their easement as part of the corridor and mission impact would need to be evaluated.

Option 3 is a combination of Options 1 and 2; it can provide the most flexibility to minimize impacts to INL missions. As with the other two options, discussions and agreements with the State of Idaho would be needed and any specific route would need to be thoroughly evaluated for impact, implementation, and operability beyond just a strategy.

INL has developed and implemented a process to identify and evaluate options to consider for placing a CUC. Any of the options will have some impact on INL missions; however, the options and evaluation process behind the options provides a rationale and basis for decision making. A significant amount of work will be required to take a CUC from a strategy to implementation and operation. 


\section{CONTENTS}

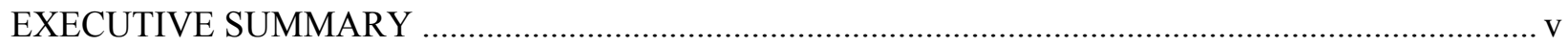

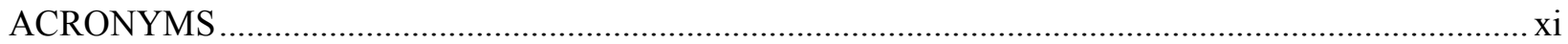

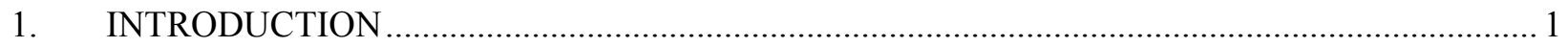

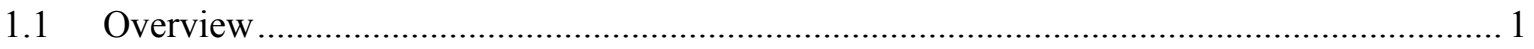

1.2 Comprehensive Utility Corridor Project ….............................................................. 1

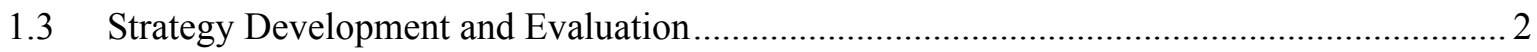

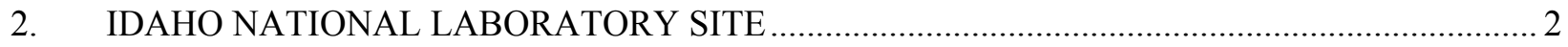

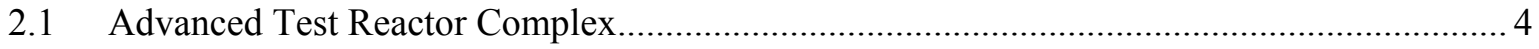

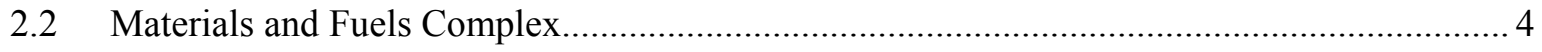

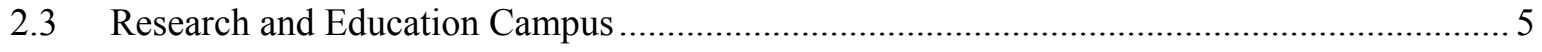

2.4 Other Sitewide Areas at the Idaho National Laboratory Site .............................................. 5

2.4.1 Central Facilities Area ............................................................................................ 5

2.4.2 Idaho Nuclear Technology and Engineering Center ......................................... 5

2.4.3 Specific Manufacturing Capability/Test Area North .............................................. 6

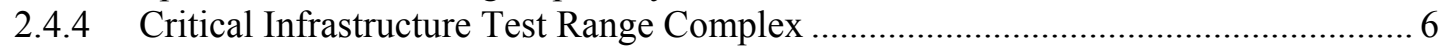

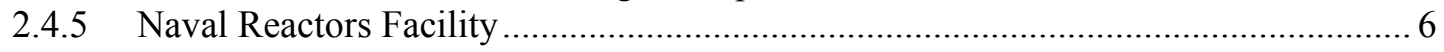

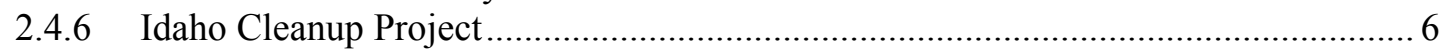

3. STRATEGY FOR EVALUATION AND OPTION PROCESS IDENTIFICATION ..................... 7

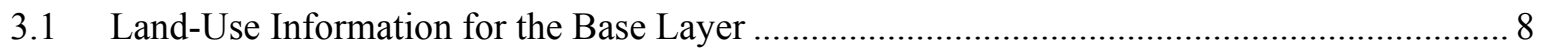

3.2 Idaho National Laboratory's Current and Future Mission Land-Use Needs ....................... 9

3.2.1 Nuclear Operation ........................................................................................ 9

3.2.2 Nuclear Science and Technology/Next Generation Nuclear Plant ............................. 10

3.2.3 Energy and Environment Science and Technology ................................................. 12

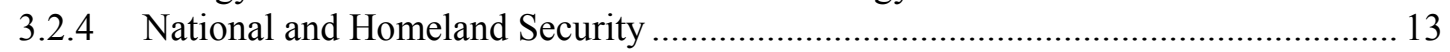

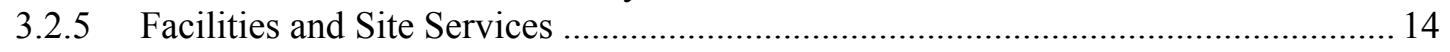

3.3 Combined INL Mission-Related Current and Future Land-Use Needs .............................. 15

3.4 Restricted and Potential Constraint Areas..................................................................... 15

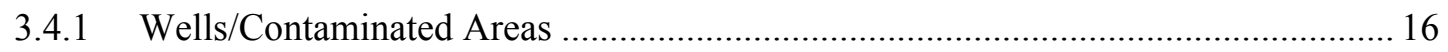

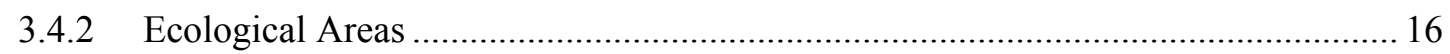

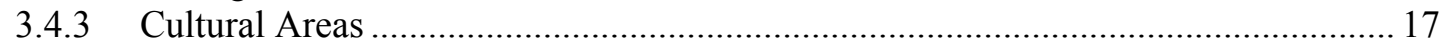

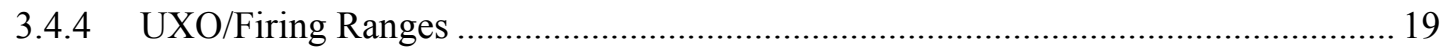




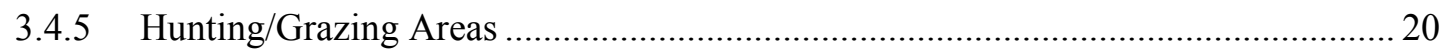

3.5 Highway and Power Line Rights-of-Way and Easements ............................................. 21

4. COMPREHENSIVE UTILITY CORRIDOR EVALUATION PROCESS ................................... 22

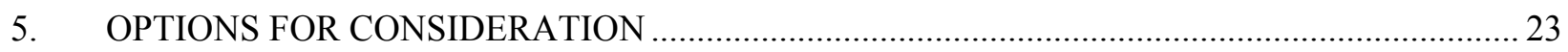

5.1 Option 1: Corridor around the Perimeter of the Idaho National Laboratory......................... 24

5.2 Option 2: Corridor along State Highways................................................................... 25

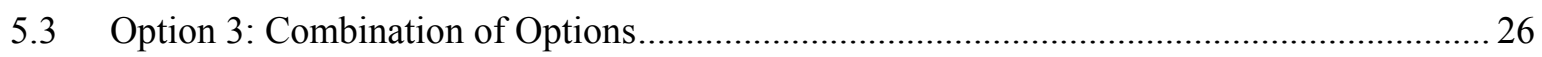

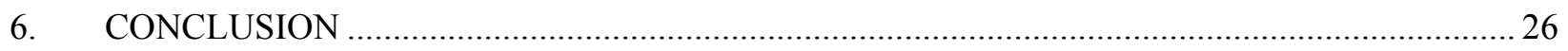

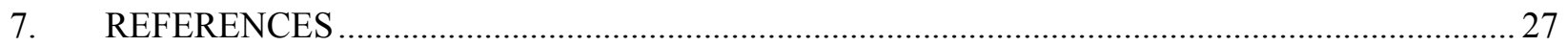

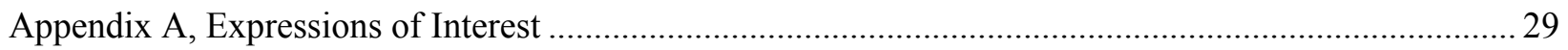

\section{FIGURES}

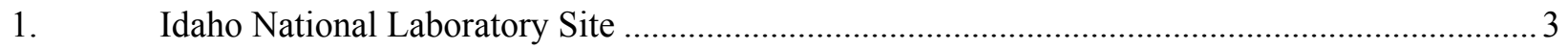

2. Idaho National Laboratory campus areas …................................................................. 3

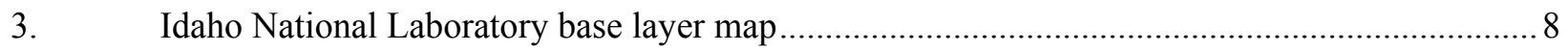

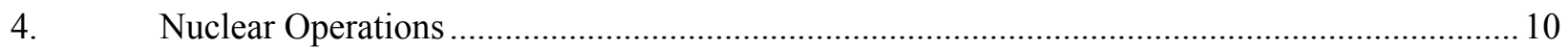

5. Nuclear Science and Technology/Next Generation Nuclear Plant ......................................... 11

6. Energy and Environment Science and Technology …..................................................... 12

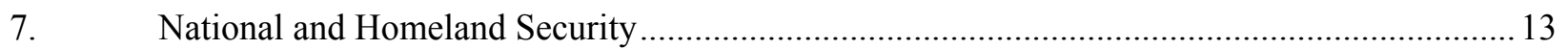

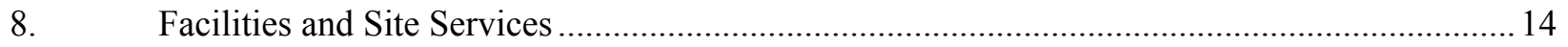

9. Combined mission-related current and future land-use needs ............................................ 15

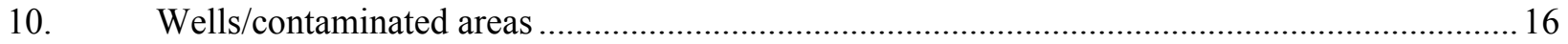

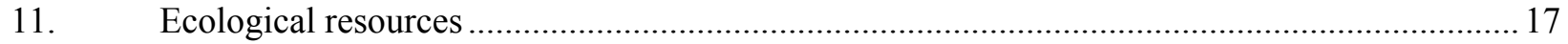

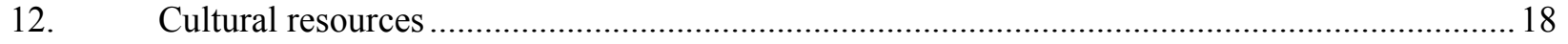

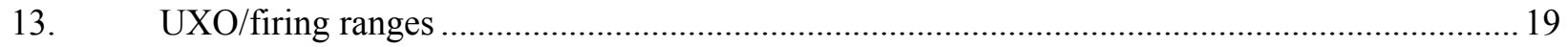

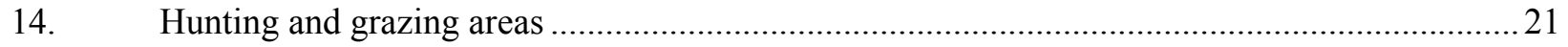




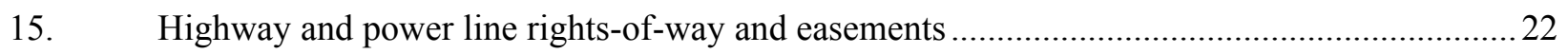

16. Comprehensive Idaho National Laboratory land-use map …............................................23

17. Option 1: Corridor around the Perimeter of the Idaho National Laboratory ............................2 24

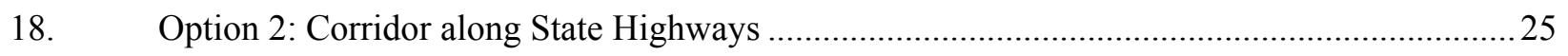

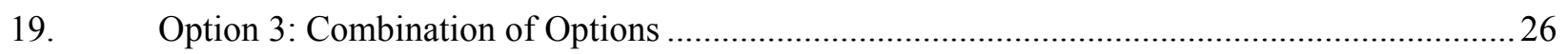

A-1. AREVA proposed comprehensive utility corridor .............................................................. 31

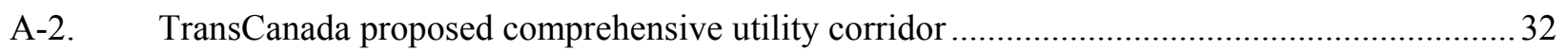

A-3. Northwestern Energy proposed comprehensive utility corridor .............................................. 33 


\section{ACRONYMS}

ATR Advanced Test Reactor

CFA Central Facilities Area

CITRC Critical Infrastructure Test Range Complex

CUC comprehensive utility corridor

DOE Department of Energy

GIS geographical information system

INL Idaho National Laboratory

INTEC Idaho Nuclear Technology and Engineering Center

MFC Materials and Fuels Complex

NGNP Next Generation Nuclear Plant

NRF Naval Reactors Facility

R\&D research and development

REC Research and Education Campus

RWMC Radioactive Waste Management Complex

SMC Specific Manufacturing Capability 


\section{Strategy for the Identification of an INL Comprehensive Utility Corridor}

\section{INTRODUCTION}

Idaho National Laboratory (INL) is a multiprogram national laboratory located in southeastern Idaho, and is a science-based, applied engineering, and research national laboratory dedicated to meeting the nation's nuclear energy and national security needs. INL has a long history of nuclear research and development (R\&D) and has been designated by the Department of Energy (DOE) as the nation's lead laboratory for nuclear energy R\&D.

\subsection{Overview}

This document details INL's process for developing and implementing a comprehensive utility corridor (CUC) strategy that will be used for interstate transmission of energy or service. The process evaluates land-use needs from a laboratory mission perspective and other INL mission and non-mission-related perspectives (e.g., the closure mission, Naval Reactors Facility (NRF), and ecological, historical, and cultural concerns).

Interest has been expressed to route interstate utilities across INL, but current and future INL mission land-use needs were not documented nor were potential corridor routes identified and evaluated for impacts to INL missions. To address these issues, DOE requested that INL develop this CUC strategy. Creating this strategy involved developing a process to evaluate activities pertinent to completion of INL missions and to identify corridor options for consideration. The intent of the strategy is to provide DOE with a basis for consistent decision-making that is linked directly to mission accomplishment.

\subsection{Comprehensive Utility Corridor Project}

Interest has been expressed in crossing INL with a utility corridor; however, INL mission land-use needs were not documented nor were potential corridor routes identified and evaluated for impacts to INL missions. As a result, DOE requested that INL develop this CUC strategy. DOE "has a responsibility to ensure the land is used primarily in support of INL missions, while protecting the environmental, ecological, and cultural aspects of the site," and this document details those requirements.

The two drivers for conducting the CUC Project are: (1) the Energy Policy Act (2005); and (2) expressions of interest in a utility corridor.

The Energy Policy Act requires federal agencies to identify energy corridors across federally controlled lands and for federal agencies to update their land-use plans to show where other utility corridors could be located. In 2009, the Bureau of Land Management issued the Approved Resource Management Plan Amendments/Record of Decision for Designation of Energy Corridors on Bureau of Land Management-Administered Lands in the 11 Western States. However, this document did not include INL.

The CUC Project was designed around DOE's position of supporting INL missions, while protecting the environmental, ecological, historical, and cultural aspects of the INL Site, as well as ensuring that existing agreements with state, local, and tribal governments and other stakeholders are considered prior to making land-use decisions. This strategy project has developed and implemented a process for identifying INL mission land-use needs for the INL Site's $889 \mathrm{mi}^{2}$ of land. The end product of this project provides DOE with a methodology for evaluating requests and developing decisions based on mission impacts. 
The following values will be applied to land-use planning decisions: (1) mission sustainability and new mission accessibility is essential for INL to maintain a leadership role in nuclear energy, other clean energy systems, and critical infrastructure protection, (2) protection and preservation of the unique ecosystems that exist at INL must be a consideration in land-use planning; and (3) land-use planning will be legally compliant and consistent with commitments to stakeholders. Easements, rights-of-way, and other third-party uses may be allowed if they do not infringe upon these values.

\subsection{Strategy Development and Evaluation}

The objective of the CUC Project is to develop a process and identify utility corridor options for consideration by mapping (with the geographic information system [GIS]) current and future mission land-use needs, along with other known factors (e.g., Comprehensive Environmental Response, Compensation, and Liability Act areas; historical sites; protected areas; roads; power lines; site campuses; and rights of way).

To ensure accuracy, a single point-of-contact from each directorate (i.e., Nuclear Operations, Nuclear Science and Technology, Energy and Environmental Science and Technology, Facility and Site Services, National and Homeland Security, and Next Generation Nuclear Plant) provided current and future mission land-use needs. The points-of-contact were responsible for assuring all programs and projects within the directorate were accurately represented on GIS maps. In addition, other mission-related functions at INL (NRF, CH2M-WG Idaho, LLC, and the Radioactive Waste Management Complex $[\mathrm{RWMC}]$ ) were asked to map their current and future mission land-use needs.

Development and integration of GIS information layers provides the capability to evaluate the INL Site from the perspective of mission land use. This provides DOE with a sound basis for decision-making.

\section{IDAHO NATIONAL LABORATORY SITE}

The INL Site occupies approximately $889 \mathrm{~m}^{2}$ in southeastern Idaho. Five counties border the INL Site: Butte, Clark, Jefferson, Bonneville, and Bingham. The INL Site consists of eight facility areas (Figure 1) situated on an expanse of undeveloped, high-desert terrain. Buildings and structures at INL are clustered within these facility areas, which are typically less than a few square miles in size and separated by miles of open land.

Three primary campus areas support INL mission accomplishment (Figure 2): (1) the Advanced Test Reactor (ATR) Complex, (2) the Materials and Fuels Complex (MFC), and (3) the Research and Education Campus (REC). REC is located in Idaho Falls, which is 25 miles east of the INL Site border. Other INL site areas include the Central Facilities Area (CFA), Idaho Nuclear Technology and Engineering Center (INTEC), Specific Manufacturing Capability (SMC)/Test Area North, the Critical Infrastructure Test Range Complex (CITRC), NRF, RWMC, and the Advanced Mixed Waste Treatment Plant. (RWMC and the Advanced Mixed Waste Treatment Plant are part of the Idaho Cleanup Project.) The remainder of the INL Site is referred to as the sitewide area, which comprises all INL land outside the boundaries of the facility areas listed above. Sitewide area infrastructure consists primarily of roads, railroads, power distribution systems, communication systems, and utility systems that serve and connect facility areas. CFA provides support services such as medical, fire suppression, transportation, security, communications, electrical power, craft support, warehousing, and instrument calibration.

Work associated with nuclear energy R\&D and other mission-related activities is performed at several INL Site locations. Currently, nuclear energy R\&D capabilities are consolidated around two site campus areas: the ATR Complex and MFC. Though they are located in separate areas, these campuses are connected by capability and function. 


\section{9,135 Acres}

889 Square Miles

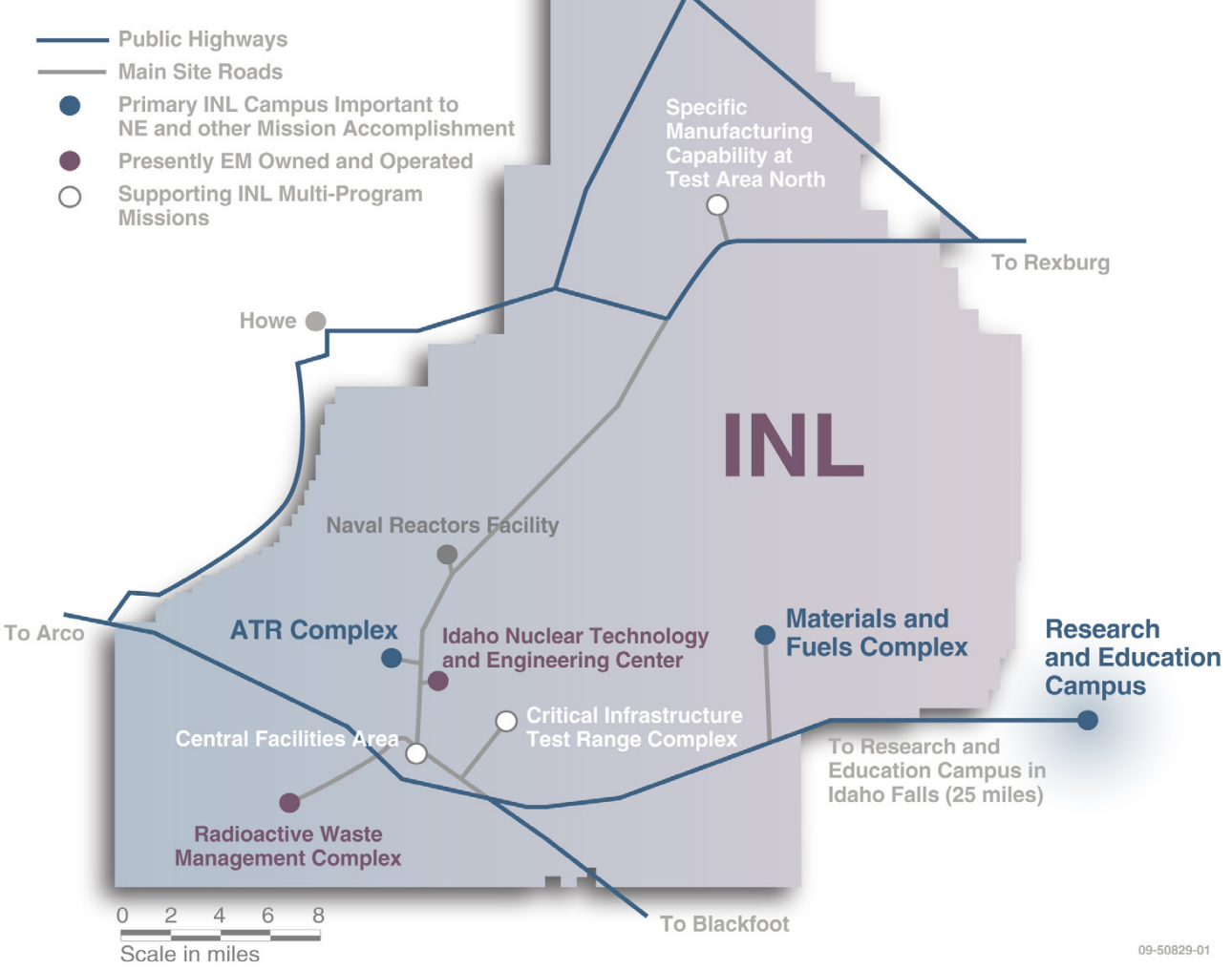

Figure 1. Idaho National Laboratory Site.

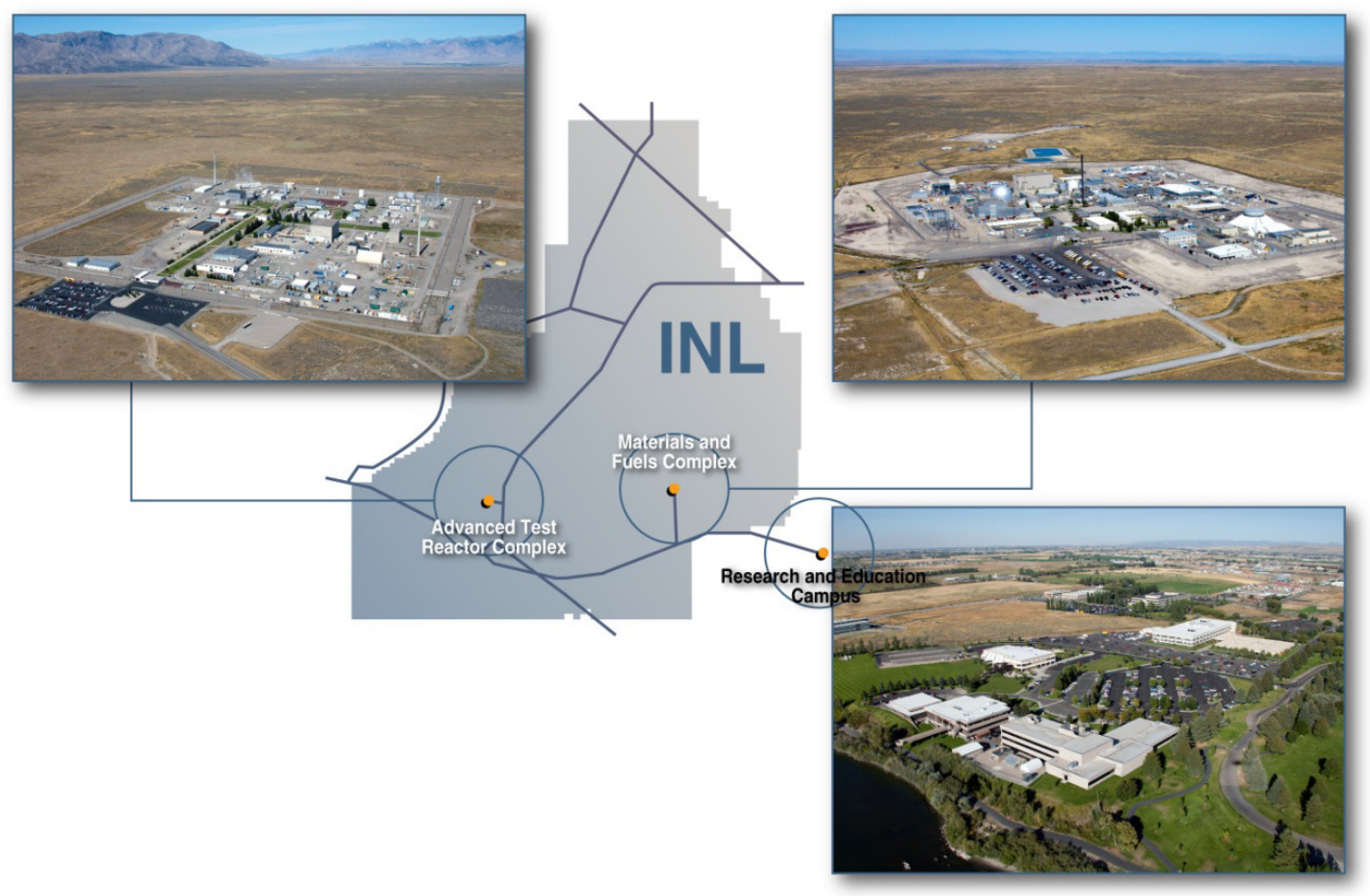

Figure 2. Idaho National Laboratory campus areas. 


\subsection{Advanced Test Reactor Complex}

The ATR Complex is located on a 102-acre fenced complex on the INL site about 47 miles west of Idaho Falls and is home to ATR, the world's most advanced materials test reactor. Established in the early 1950s, the ATR Complex has been the site of three experimental nuclear reactors, along with associated physics and chemistry laboratories and support facilities.

A low-temperature, pressurized, water-cooled reactor for steady-state irradiation, ATR is fully subscribed to meeting the needs of the DOE Office of Nuclear Energy, Science, and Technology; Office of Naval Reactors; National Nuclear Security Administration, and many other research users. Other facilities in the ATR Complex include the associated ATR Critical Facility, a test-train assembly facility, and a supporting radioanalytical laboratory.

Historically, the ATR Complex has supported fuel development for the Navy's nuclear propulsion program. Over the last decade, its use has expanded into other mission areas that include particle fuel development for the high-temperature gas reactor, minor actinide-bearing fuel development, and low-enriched fuel for the National Nuclear Security Administration's Reduced Enrichment for Research and Test Reactor Program, which is part of the Global Threat Reduction Initiative. ATR is one of two test reactors designated by a DOE record of decision as suitable for future production of $\mathrm{Pu}-238$.

ATR's primary focus is continued operation of fuel and materials irradiation testing, nuclear safety research, and nuclear isotope production. Given this mission, the ATR Complex is essential to developing advanced, safer, more efficient, and proliferation-resistant nuclear reactors, in addition to producing a number of valuable medical, commercial, and government-owned isotopes. An ATR life-extension project is underway to develop and implement the necessary actions and strategies for ensuring that ATR remains vital for future nuclear energy research and testing needs. A recently completed ATR review also provided recommendations that would make ATR contemporary with commercial power reactors and supporting continued operation of ATR into the foreseeable future. Efforts also are underway to determine the feasibility of ATR serving as a user facility with enhanced accessibility to academic and industrial researchers, in accordance with the 2005 Energy Policy Act. Fusion energy research also is conducted at the ATR Complex in the Safety and Tritium Applied Research Facility.

\subsection{Materials and Fuels Complex}

MFC is located on a 1,707-acre tract at the INL Site about 30 miles west of Idaho Falls. This campus is dedicated to performing fundamental research and technology development for reactor fuels, the fuel cycle, and related materials. MFC is the center of fuel fabrication, and post-irradiation testing at INL.

Projects at MFC primarily focus on developing innovative solutions for nuclear power technology, including the following:

- Nuclear fuel development, with the objectives of higher burn-up and higher transuranic content

- Separations development, with the objectives of lower costs and minimal environmental impact

- Fast reactor development, with the objectives of lower costs and higher safety.

Results of this work are disseminated openly to the scientific community or made available to private industry. The quality of such work depends on open dialogue and exchange of information. In this capacity, MFC hosts many foreign visitors and assignees, with whom active information exchange is encouraged.

Other projects at MFC support R\&D, training for the Department of Homeland Security, space nuclear research and processing for the National Aeronautics and Space Administration, and other research involving commercial interests. 
MFC is home to the Transient Reactor Experiment and Test Facility and the Neutron Radiography Reactor, which is a TRIGA reactor (i.e., training, research, and isotope reactor built by General Atomics) used for neutron radiography. It also houses hot-cell facilities used for post-irradiation examination, advanced separations, and research waste; analytical laboratories; an electron microscopy laboratory for isotopic and chemical analyses and nanometer-scale analysis of material samples from MFC research facilities; and co-located fuel fabrication glovebox lines. MFC also operates a facility for final assembly and testing of radioisotope power systems.

\subsection{Research and Education Campus}

REC, located in Idaho Falls, is home to INL administration facilities (located in the Engineering Research Office Building and the Willow Creek Building) and a wide variety of other facilities. At the INL Research Center, scientists working in dozens of laboratories conduct cutting-edge research in fields as varied as robotics, genetics, biology, chemistry, metallurgy, computational science, and hydropower. The Center for Advanced Energy Studies, which opened in 2009, houses the Energy Policy Institute. Other facilities support national security programs and INL precision machining and glass shops.

\subsection{Other Sitewide Areas at the Idaho National Laboratory Site}

Sitewide areas include land and facilities outside the boundaries of INL's facility areas (i.e., REC, MFC, and ATR). These areas consists of facility areas outside the main campus areas, roads, railroads, power distribution systems, communication systems, guard posts, live fire ranges, explosive ranges, training facilities, pump houses, and landfill support structures. It also consists of offsite facilities, including Howe Peak and East Butte.

Some of the facility areas included in the sitewide area are CFA, INTEC, SMC, CITRC, the Firing Range Complex (a security force training center), the Experimental Breeder Reactor-I historical site, and the site entrance and exit guard gate facilities. Also, two Fort St. Vrain facilities and three offsite, leased facilities are grouped with the INL sitewide facilities for administrative purposes.

\subsubsection{Central Facilities Area}

CFA is located approximately 50 miles west of Idaho Falls on a 968-acre tract. The Navy built the original facilities at CFA in the early 1940s when the area was used as a gunnery range. At the end of World War II, the INL Site was designated the National Reactor Testing Station, and CFA was converted to a centralized service area to provide support for numerous reactor testing complexes at scattered locations across the INL Site. The INL Site has undergone a number of varying mission reassignments throughout the years and the landscape has been modified to fit the changing work activities. However, CFA's overarching purpose has been to provide efficient, centralized support functions, services, and facilities for programmatic and nonprogrammatic operations of all INL Site contractors and DOE. The array of CFA's administrative and support services has included buildings for medical, fire suppression, transportation, security, communications, electrical power, craft support, warehousing, and instrument calibration.

\subsubsection{Idaho Nuclear Technology and Engineering Center}

The INTEC area includes operations that focus primarily on special nuclear materials disposition, legacy spent nuclear fuel disposition, and radioactive waste disposition. Cleanup and closure goals include the following:

- Treatment of sodium-bearing waste

- Closure and remediation of the tank farm

- Packaging and dry storage of spent nuclear fuel

- Disposition of radioactive waste calcine 
- Elimination of buildings and structures

- Completion of soil and groundwater remediation.

Currently owned and operated by the DOE Office of Environmental Management, INTEC operated until 1992 to recover highly enriched uranium from government reactors and convert liquid, high-level waste into a more stable, solid granular material suitable for long-term storage. In the 1980s, second-generation facilities that housed advanced fuel storage and dissolution, remote maintenance capabilities, and sampling and analytical technologies replaced the earlier facilities. Today, environmental cleanup at INTEC is nearing completion and most of its facilities are or will be placed in long-term stewardship.

\subsubsection{Specific Manufacturing Capability/Test Area North}

The SMC program is located at Test Area North, which is situated in the north-central portion of the INL Site. The Department of Defense funds the SMC program, whose mission is to provide facilities, equipment, and trained personnel to support U.S. Army missions.

\subsubsection{Critical Infrastructure Test Range Complex}

The CITRC area was originally developed in the late 1950s as the Stationary Power Excursion Reactor Test area. It was composed of four reactors and a control area. All of the reactors were eventually deactivated, decontaminated, and the facilities were placed back in service to support an array of different programs. In 2004, the facilities were designated for the National and Homeland Security Program and renamed the CITRC area.

CITRC supports National and Homeland Security missions, including program and project testing (i.e., critical infrastructure resilience and nonproliferation testing and demonstration). Wireless test-bed operations, power line and grid testing, unmanned aerial vehicle testing, accelerator testing, explosives detection, and radiological counter-terrorism emergency response training are performed at CITRC.

\subsubsection{Naval Reactors Facility}

NRF was established in 1950 to support development of the U.S. Navy Nuclear Propulsion Program. From the early 1950s to the mid 1990s, NRF built and operated prototype nuclear propulsion plants for submarines and aircraft carriers. For over 50 years, NRF has supported the Navy's nuclear-powered fleet by testing reactor designs, receiving nuclear fuel for examination and storage, and training sailors to operate shipboard nuclear power plants.

NRF is operated by Bechtel Bettis, Inc. under contract with and direct supervision of the Naval Nuclear Propulsion Program. NRF is not under the purview of the DOE Idaho Operations Office. However, based on a memorandum of understanding between the Pittsburgh Naval Reactors Office and the DOE Idaho Operations Office, INL has agreed to provide support services to NRF, including, but not limited to, bus transportation, motor vehicle and equipment use, electrical power, electrical distribution system management, fire department services and firefighter training, telephone and other communications services, roads and grounds maintenance (outside NRF boundaries), medical support services, railroad operations, and specialized machine shop services.

\subsubsection{Idaho Cleanup Project}

The Idaho Cleanup Project mission is to support the INL mission and vision. The Idaho Cleanup Project's goal is to complete environmental cleanup in a safe, cost-effective manner, consistent with the principles of the DOE Office of Environmental Management Closure Planning Guidance Document, dated June 1, 2004. The objectives include the following:

- Objective EM-1: Complete efforts to safely accelerate risk reduction, footprint reduction, and continued protection of the Snake River Aquifer 
- Objective EM-2: Complete shipment of transuranic waste offsite and meet commitments in the Idaho Settlement Agreement

- Objective EM-3: Identify innovative approaches to post 2012 work scope such as calcine, spent fuel, and institutional control

- Objective EM-4: Complete establishment of federal baseline management and government-furnished services and items delivery systems and apply to administration of new contracts.

2.4.6.1 Radioactive Waste Management Complex. RWMC's current mission involves interim storage of transuranic waste, shipment of stored transuranic waste for permanent disposal, and disposal of low-level waste.

Much of the low-level waste generated from INL's DOE Office of Nuclear Energy activities is disposed of in the Subsurface Disposal Area at RWMC. However, the Subsurface Disposal Area is scheduled for closure by Fiscal Year 2017. Consequently, INL has been directed to investigate disposal alternatives for low-level waste.

\subsubsection{Advanced Mixed Waste Treatment Plant. The specific Advanced Mixed Waste} Treatment Plant requirements are to retrieve, characterize, treat, and dispose of transuranic waste. The waste, currently stored in drums, boxes, and bins at the RWMC Transuranic Storage Area, is anticipated to consist of heterogeneous mixtures of various solid materials, including paper, cloth, plastic, rubber, glass, graphite, bricks, concrete, metals, nitrate salts, process sludges, miscellaneous components, and some absorbed liquids. Most of the waste is believed to contain both Resource Conservation and Recovery Act hazardous waste constituents and radioactivity, classifying it as mixed waste. Some waste also may contain Toxic Substances Control Act-regulated materials such as polychlorinated biphenyls and asbestos.

\section{STRATEGY FOR EVALUATION AND OPTION PROCESS IDENTIFICATION}

The process for developing a CUC strategy consists of GIS mapping in four phases that, once developed, contain information that could be evaluated to identify mission impacts. The GIS mapping phases are as follows:

1. INL Base Layer Map - This phase geospatially references all stationary geographical features and identifies INL campuses, sitewide areas, roads, and other existing infrastructure.

2. INL Current and Future Mission Land-Use Needs - This phase provides a 30 -year look into the future for INL programs to identify land use needs to support missions.

3. INL Restricted and Potential Constraint Areas - This phase includes capturing wells, contaminated areas, unexploded ordinance areas, firing ranges, cultural areas, ecological areas, easements, hunting areas, and grazing areas.

4. State Highway and Power Line Rights-of-Way and Easements - This phase identifies locations of state highways and power line rights-of-way and easements across the site.

Once the data layers in each of the phases were identified and mapped, the initial evaluation process began.

All of the information generated was depicted as individual data layers in GIS format. This allowed for layering of information in a way that the total picture of INL land-use needs could be created for evaluation purposes. 


\subsection{Land-Use Information for the Base Layer}

Development of an INL base data layer was the first phase of the process. In order to develop the base layer, an understanding of the permanent features on the INL Site was needed. This layer forms the foundation for the strategy development process and is shown in Figure 3. The base layer includes roadways, campuses, site areas (e.g., MFC, ATR Complex, INTEC, RWMC, and NRF), rivers/streams, existing power transmission lines, county boundaries, towns located around the INL perimeter, and key topographic features.

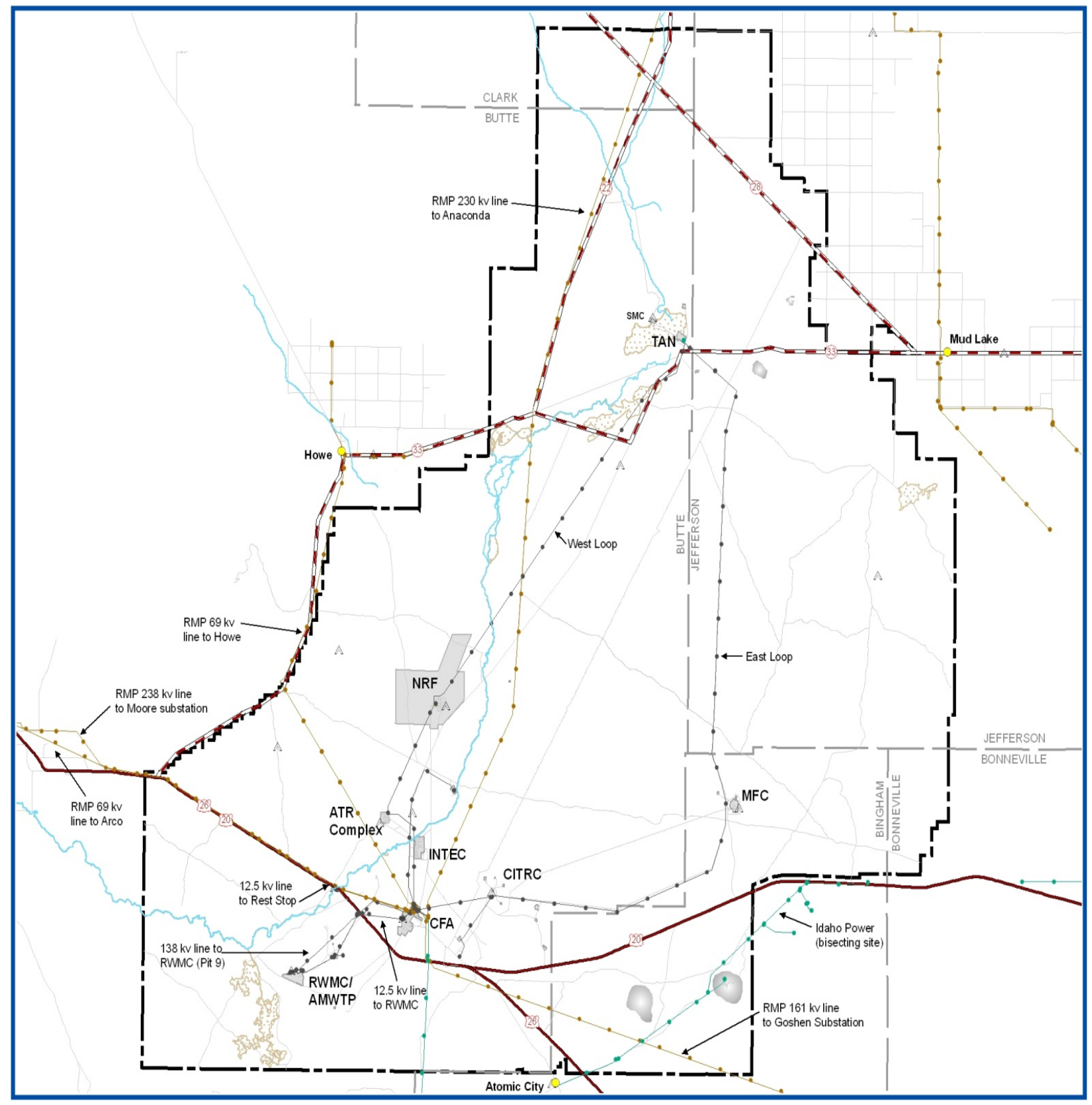

Figure 3. Idaho National Laboratory base layer map. 


\subsection{Idaho National Laboratory's Current and Future Mission Land-Use Needs}

The second phase to the strategy development process involved identification of INL's current and future mission land-use needs with a 30-year look into the future. To complete this task, a single point of contact was identified for each directorate. These points of contact worked within their respective directorates to ensure accuracy of mission land-use needs 30 years into the future; these land-use needs are described in the following subsections.

\subsubsection{Nuclear Operation}

Building on its legacy responsibilities, infrastructure, and expertise, INL's nuclear energy mission, including Nuclear Operations and Nuclear Science and Technology, is to perform science-based R\&D that is focused on advanced nuclear technologies addressing the objectives of the DOE Nuclear Energy Roadmap and promoting revitalization of the nation's nuclear power industry. INL coordinates and participates with DOE Office of Nuclear Energy to provide assistance with the following Nuclear Energy Roadmap objectives:

1. Develop technologies and other solutions that can improve reliability, sustain safety, and extend the life of the current reactors.

This objective is accomplished by supporting and conducting long-term research needed to inform component refurbishment and replacement strategies, performance enhancements, plant license extensions, and age-related regulatory oversight decisions. The R\&D focus is on aging phenomena and issues that require long-term research and are generic to reactor type.

2. Develop improvements in the affordability of new reactors to enable nuclear energy to help meet energy security and climate change goals.

These improvements will address barriers associated with deployment of new nuclear power plants, including advanced designs such as small modular, fast-spectrum, and high-temperature reactors with advanced technologies that could support electric and nonelectric applications of nuclear energy.

3. Develop a sustainable fuel cycle.

$\mathrm{R} \& \mathrm{D}$ focuses on domestic nuclear-fuel recycling, waste management technologies, and optimized solutions to reduce proliferation risks under the following fuel-cycle management scenarios:

- Once-through fuel cycle - Optimize the fuel cycle to minimize costs and environmental impacts and maximize safety and proliferation resistance

- Modified open cycle - Develop nuclear fuel that better uses the fuel resource, reduces the quantity of actinides in used fuel, and uses separations and fuel-processing technologies for used light water reactor fuel to extract more energy from the same mass of material

- Full recycle - Recycle all actinides in thermal or fast-spectrum systems to reduce radiotoxicity of the waste, while more fully using the uranium resources.

Unlike R\&D Objectives 1 and 2, management of used nuclear fuel and development of fuel-cycle technologies are primarily the government's responsibilities because the government is legally responsible for used nuclear fuel. Therefore, the government primarily leads the necessary R\&D. However, early and continuous industry collaboration is important because any technologies that are developed will ultimately be implemented by commercial entities.

4. Understand and minimize the risk of nuclear proliferation and terrorism. 
This objective will enable access to nuclear energy benefits without increasing nuclear proliferation and security risks. It incorporates simultaneous development of nuclear fuel-cycle technology, safeguards and security approaches, technologies and systems, new proliferation risk-assessment tools, and nonproliferation frameworks and protocols. While National Nuclear Security

Administration laboratories lead R\&D associated with safeguards by design, INL fuel-cycle facilities (i.e., the Fuel Conditioning Facility) will support development of approaches and testing of process control instrumentation and new sampling systems that provide near real-time accountability.

Figure 4 shows the mission land-use needs for the Nuclear Operations directorate. The majority of Nuclear Operations will take place at four INL locations: MFC, ATR Complex, INTEC, and SMC. The current land-use area is identified in yellow and future land-use needs are identified in blue. These areas are, for the most part, confined to their existing footprint; however, in some cases the footprint is expected to increase.

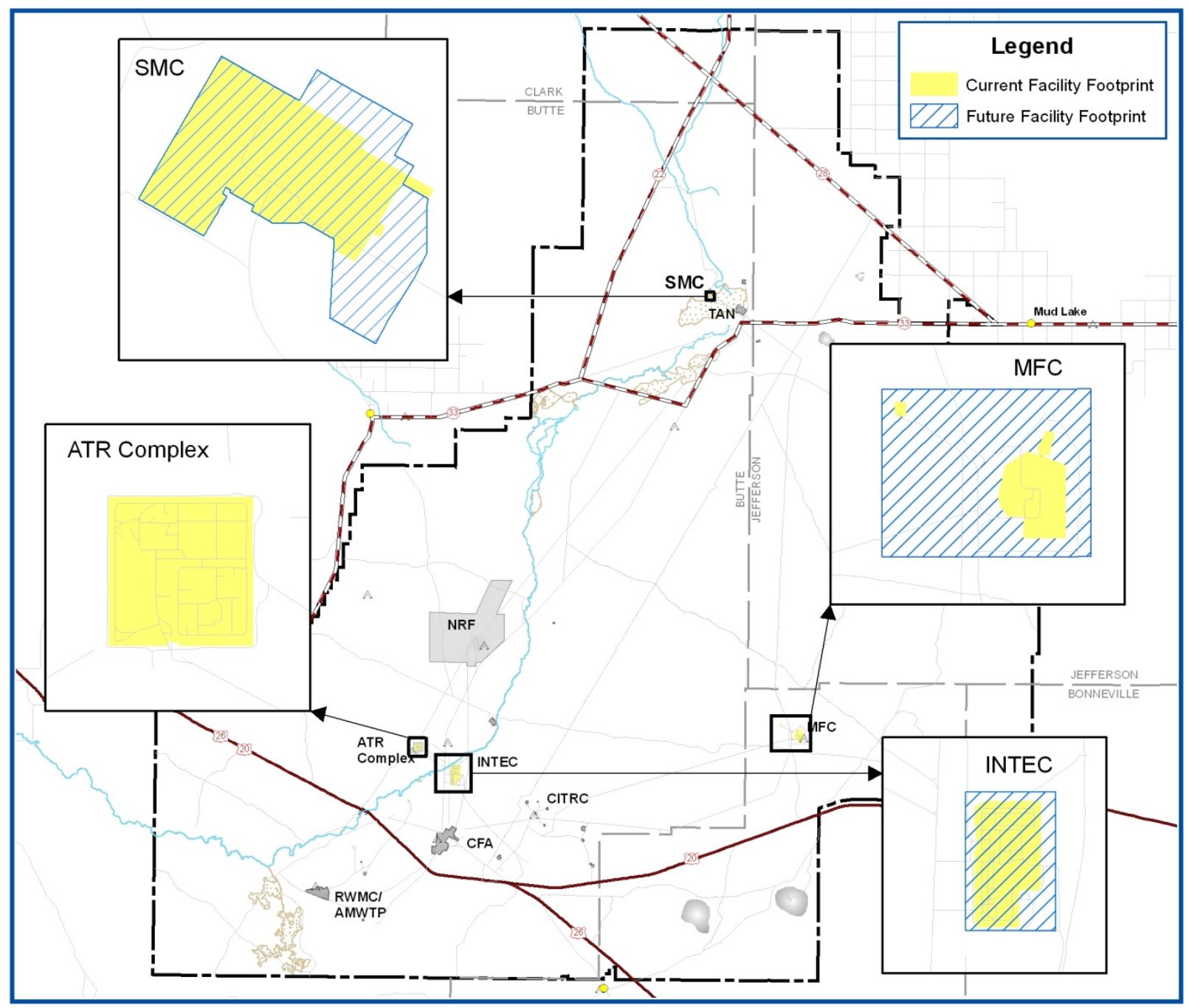

Figure 4. Nuclear Operations.

\subsubsection{Nuclear Science and Technology/Next Generation Nuclear Plant}

The Nuclear Science and Technology Directorate builds and maintains technical and programmatic leadership necessary to lead the nation's nuclear energy research, development, demonstration, and deployment. Key to the success of those programs is effective engagement and integration with each of 
the principal sectors of the nuclear energy enterprise, including DOE, industry, universities, and regulators.

The Next Generation Nuclear Plant (NGNP) project engages corporations depended on for gasoline, plastics, and fertilizer with a progressive approach to energy production. NGNP is striving to create a closer relationship between the major commercial energy consumers and the production lines that support those industries. The project is developing a high-temperature, gas-cooled reactor to produce energy that can run both a primary and a secondary industrial application. The heat generated by the high-temperature reactor can be used to run more efficient turbines, produce electricity for homes, and use the residual steam to manufacture plastic components from raw materials or generate ammonia for fertilizer. Numerous industrial applications and energy distribution methods may be integrated into the NGNP operation.

Figure 5 shows the zone where the Nuclear Science and Technology Program will be conducted and indicates the areas where the NGNP reactor would be placed. The land-use area is identified in blue and green; it extends between MFC and ATR and includes CFA and INTEC. There is close interaction between sites and previous seismic studies have been conducted in the green areas to support NGNP.

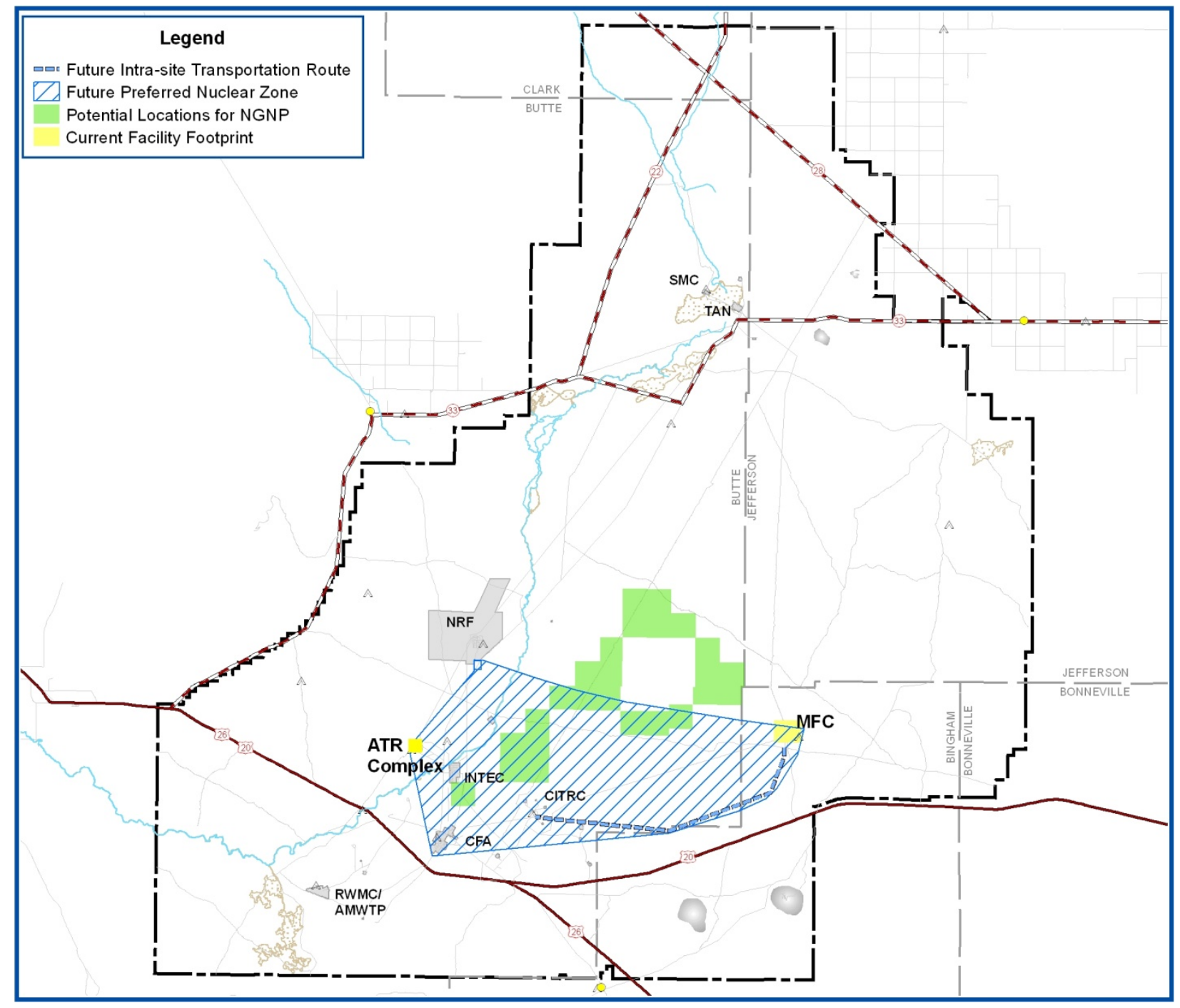

Figure 5. Nuclear Science and Technology/Next Generation Nuclear Plant. 


\subsubsection{Energy and Environment Science and Technology}

INL's Energy and Environment Science and Technology mission is derived from engineering and research capabilities in specific areas of energy supply (i.e., biomass assembly, testing of advanced vehicles, and development of catalysts) and in developing engineering solutions for integration of energy systems.

Most of Energy and Environment's research is conducted at REC and soon will be housed in the new Energy Systems Laboratory. Part of the Energy and Environment mission is supporting green energy R\&D. Several areas that support alternative energy and energy conservation are located on the INL Site, including potential wind turbine locations. An unmanned aerial vehicle (shown as UAV on Figure 6) landing strip also is part of this mission. Figure 6 shows the locations where wind turbines could be placed and where the unmanned aerial vehicle landing strip is located.

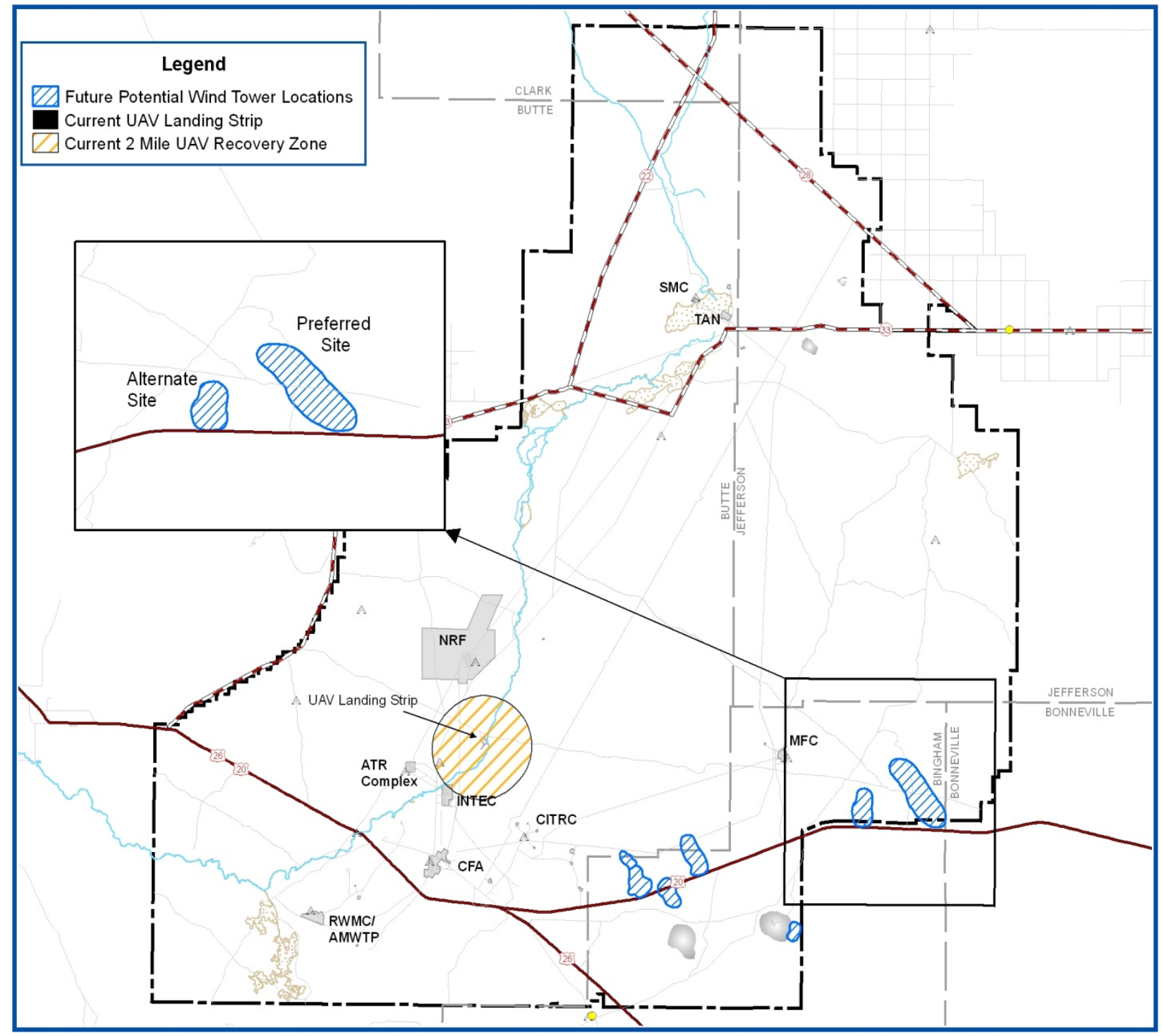

Figure 6. Energy and Environment Science and Technology. 


\subsubsection{National and Homeland Security}

The National and Homeland Security mission at INL synergizes with INL's nuclear mission and focuses on critical infrastructure protection and nuclear nonproliferation. Nuclear nonproliferation includes the areas of safeguards and security, and signatures, detection, and response. The Critical Infrastructure Protection mission focuses on reducing cyber and physical security risks. INL has established unique capabilities in cyber security, wireless communications, electric power, infrastructure modeling, and armor and explosives technologies. The nuclear power industry is poised to take a significant technological step from legacy analog technology to resilient digital systems in both new reactors and upgrades to the existing fleet. This migration will require significant $R \& D$ to resolve technical barriers and ensure the digital technologies employed are adequately protected against cyber attacks. INL has extensive experience working with the non-nuclear energy sector and is engaging the Nuclear Energy Institute and the Nuclear Regulatory Commission in security issues related to nuclear plants.

Figure 7 identifies the areas within INL that support National and Homeland Security missions. These missions cover a wide array of customers and, in some cases, require remote locations. To support some of the electrical power grid functions, a new electric grid test bed is proposed (outlined in blue). This grid will allow independent testing without interuption to the INL power grid. Other proposed areas include several test ranges.

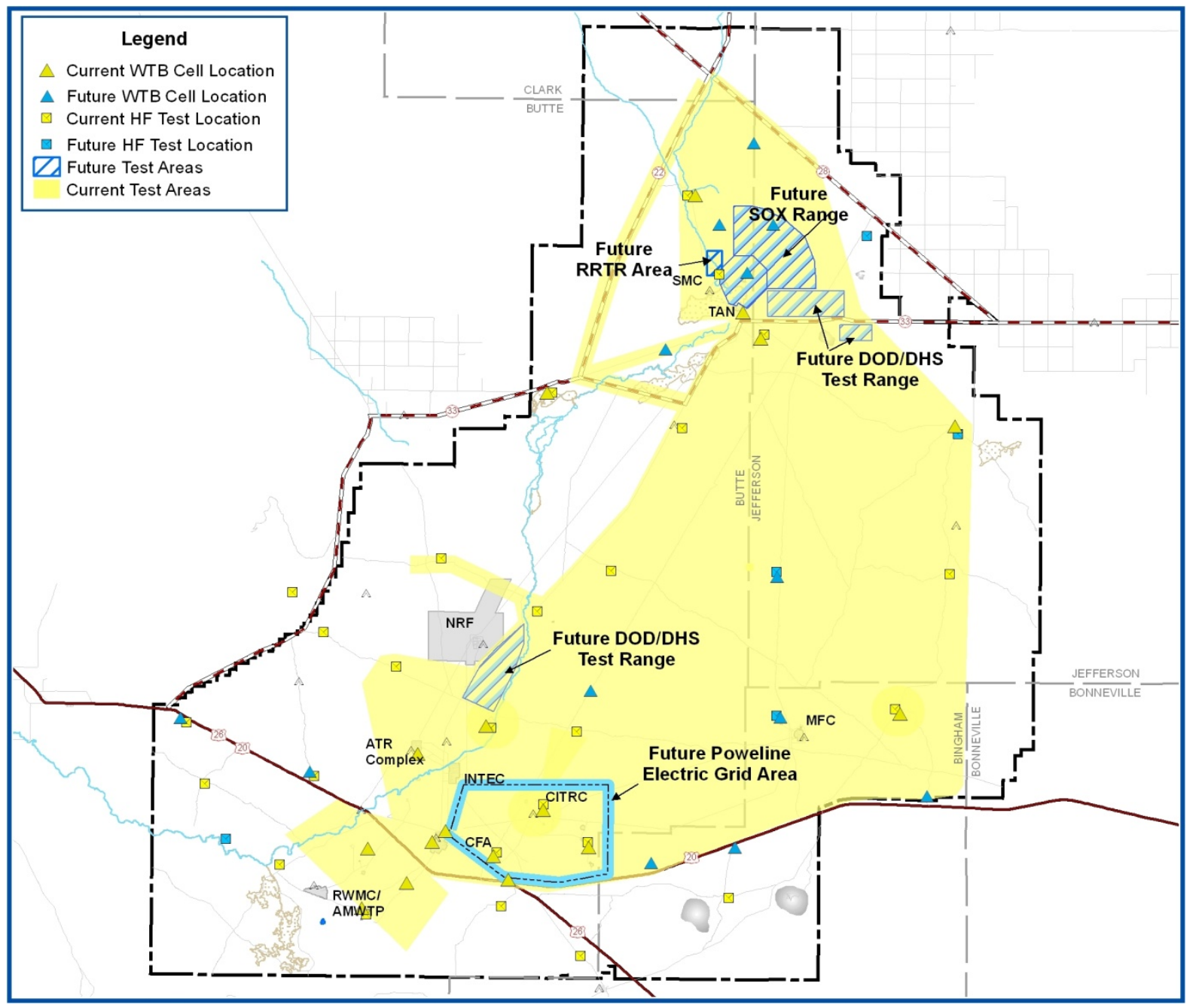

Figure 7. National and Homeland Security. 


\subsubsection{Facilities and Site Services}

The majority of the Facilities and Site Services activities are within the INL campuses and other INL Site areas such as Test Area North, INTEC, and CFA (as shown on the base layer map, Figure 3). However, there are other areas that Facilities and Site Services manages outside of the base layer map. These include the gravel or borrow pits, cell towers, and the planned remote-handled low-level waste disposal facility. Figure 8 shows these Facilities and Site Services areas in addition to what is shown on the base layer map (Figure 3).

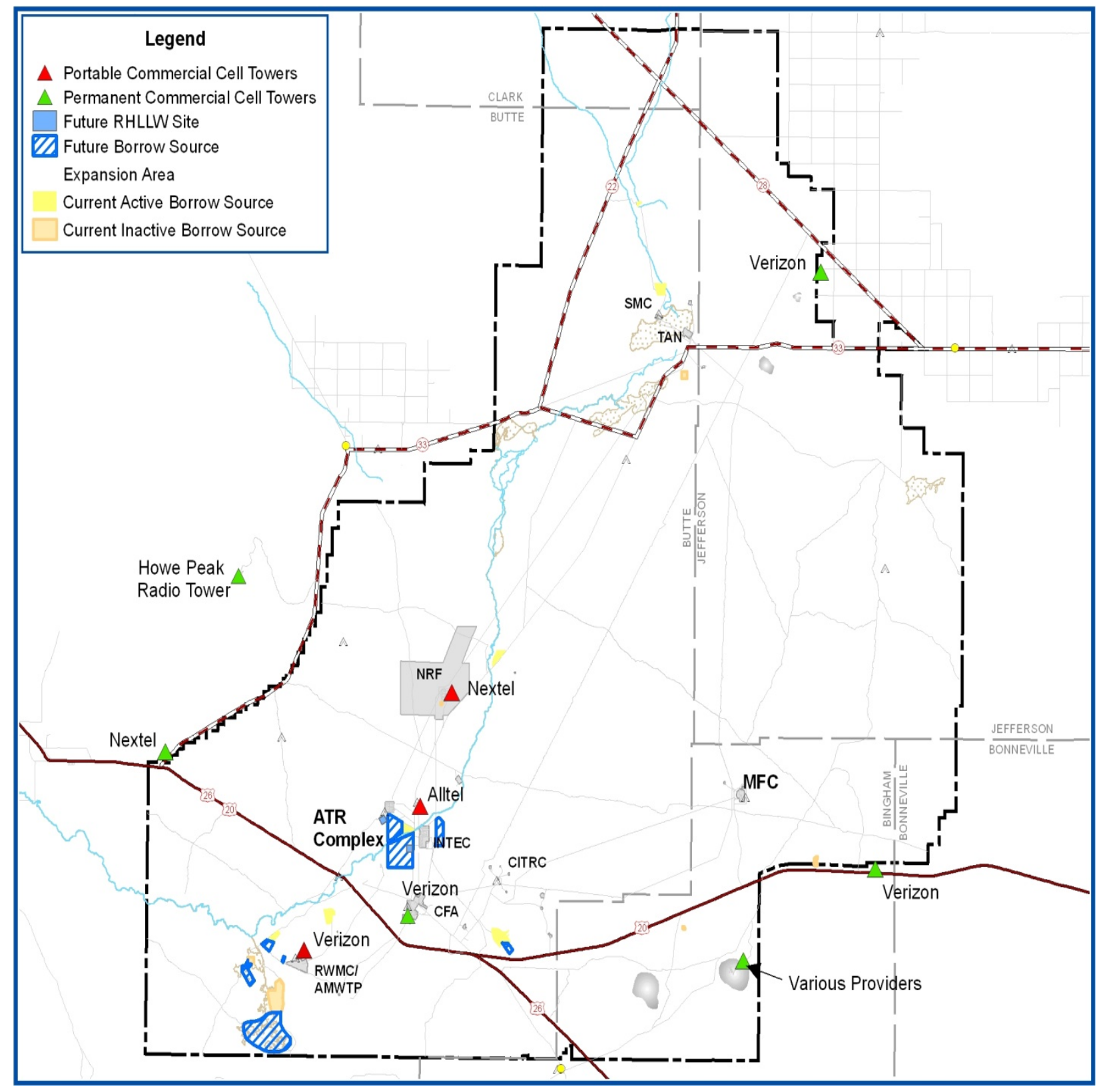

Figure 8. Facilities and Site Services. 


\subsection{Combined INL Mission-Related Current and Future Land-Use Needs}

Previous mission land-use need maps (Figures 3 through 8) were directorate specific. In order to visualize what the INL Site looks like with all individual directorate-level mission land-use needs layered on top of each other, a combined INL mission-related current and future land-use need map was created. Figure 9 illustrates the GIS layering into one map, which was used to initiate the evaluation process and initially determine areas that might support options for consideration.

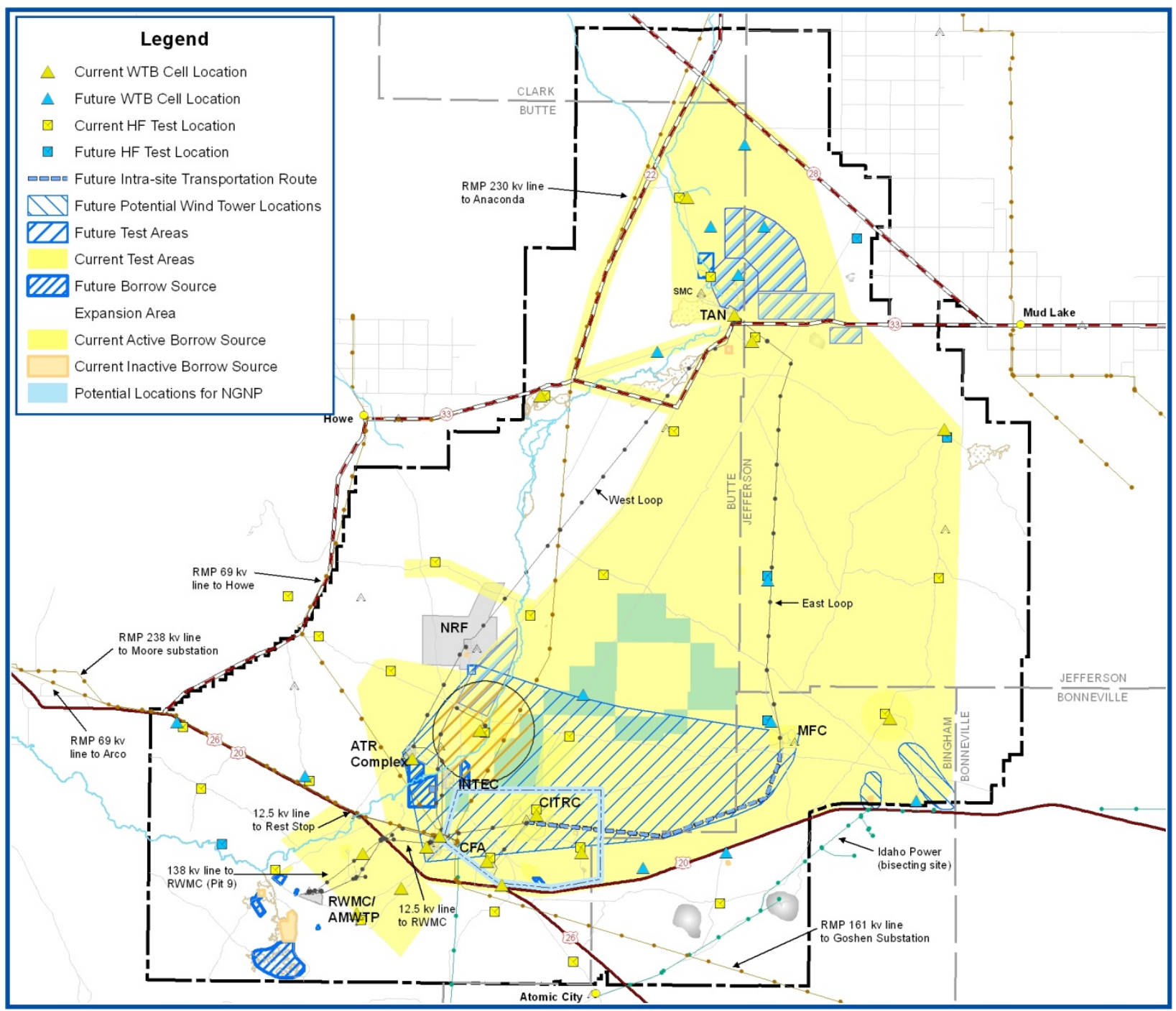

Figure 9. Combined mission-related current and future land-use needs.

\subsection{Restricted and Potential Constraint Areas}

Following the determination of mission land-use needs, other restricted and potential constraint areas were identified and mapped using INL geospatial capabilities. This section identifies those areas across the INL Site that could restrict or constrain placement. These individual data layers needed to be properly identified and mapped to allow prudent decisions concerning the viability of those areas. The potential restriction or constraint areas include wells; contaminated areas; ecological and cultural areas; unexploded 
ordinance and firing range areas; hunting areas; and grazing areas. Each of these areas is described in the following subsections.

\subsubsection{Wells/Contaminated Areas}

There are numerous wells and areas of contamination across the INL Site (Figure 10). The wells consist of potable water wells and monitoring wells. Monitoring wells are typically located in and around areas where environmental restoration activities are taking place and are used to detect the accumulation of contaminants into the groundwater should it occur.

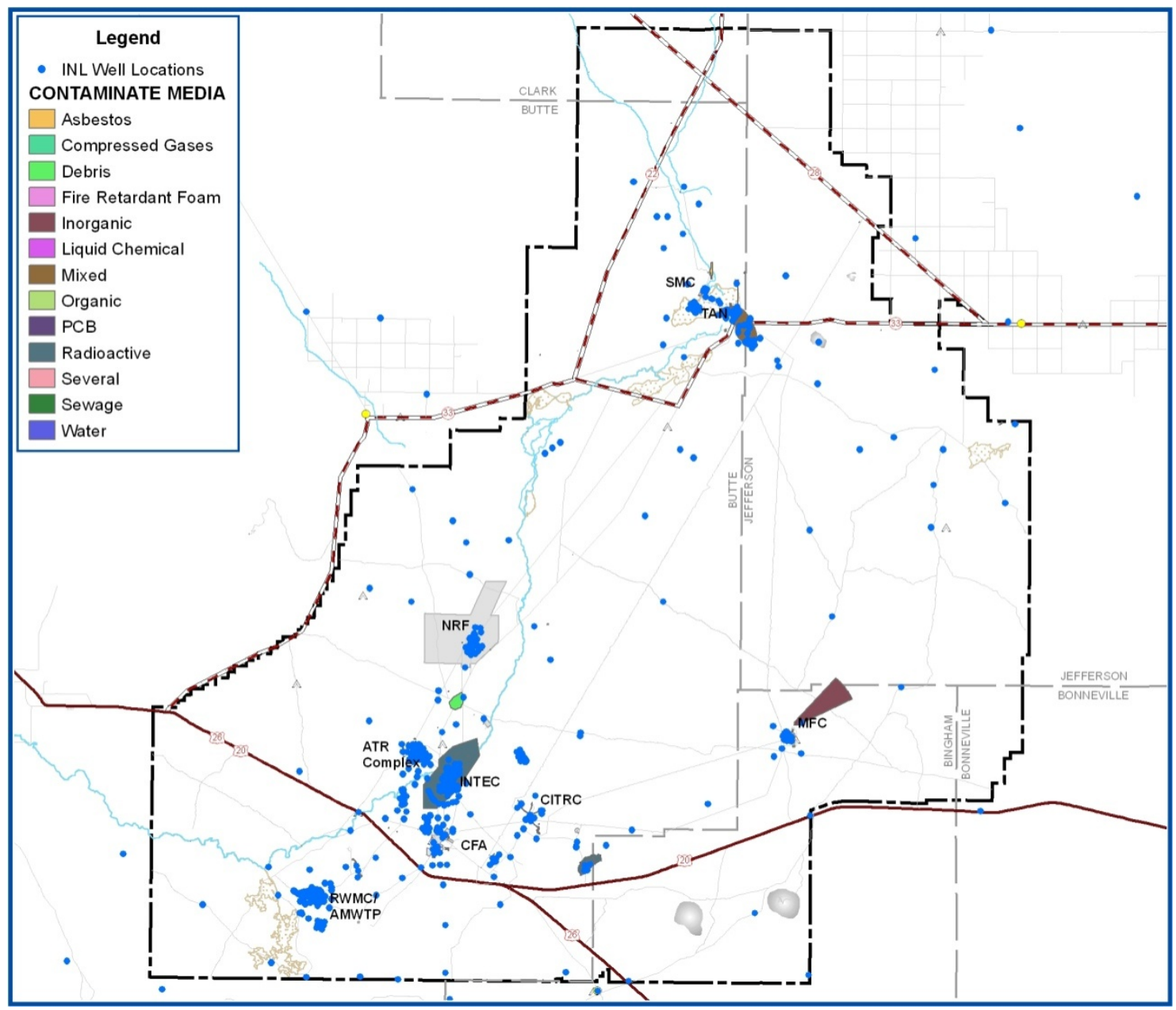

Figure 10. Wells/contaminated areas.

\subsubsection{Ecological Areas}

Fossils from several time periods have been found in southern Idaho near and within INL Site boundaries, from ancient marine invertebrates in the limestones of the central and eastern mountains to packrat middens and trees a few centuries old on the basaltic plains.

Dominated by big sagebrush, this ecosystem is home to more than 400 species of plants that provide habitat for 250 wildlife species, including mule deer, pronghorn antelope, sage grouse, burrowing owls, pygmy rabbits, and elk. Some animals of the sagebrush steppe require sagebrush to survive. For some, sagebrush is a food source, especially in winter, when many plants are covered by snow. For others, sagebrush provides protective cover. 
The sagebrush "steppe," a Russian word meaning "treeless plain," is a temperate, semi-arid landscape of shrubs and widely spaced bunchgrasses. With an average elevation of 4,900 feet $(1,500 \mathrm{~m})$, this area is at a northern tip of the largest desert in the United States, the Great Basin Desert. Winter on the steppe is cold and windy, with soils remaining frozen and snow covering the ground for 3 months or more. Most precipitation comes in the form of snow, which can accumulate in drifts that last into late spring. Examples of sagebrush obligate species are pygmy rabbits, sage grouse, sage thrashers, sage sparrows, sagebrush voles, and sagebrush lizards.

In water-limited ecosystems, surface waters like the Big Lost River can increase plant and animal diversity. Riparian areas provide additional moisture for wetland plants, cottonwood trees for nesting raptors, and habitat for waterfowl, shorebirds, and trout. The Big Lost River probably flowed here year round before upstream diversions reduced flows to the lower river. It now remains dry most of the year. Figure 11 indicates the ecological areas, including known sage-grouse leks, pygmy rabbit habitat, and possible cultural resource areas.

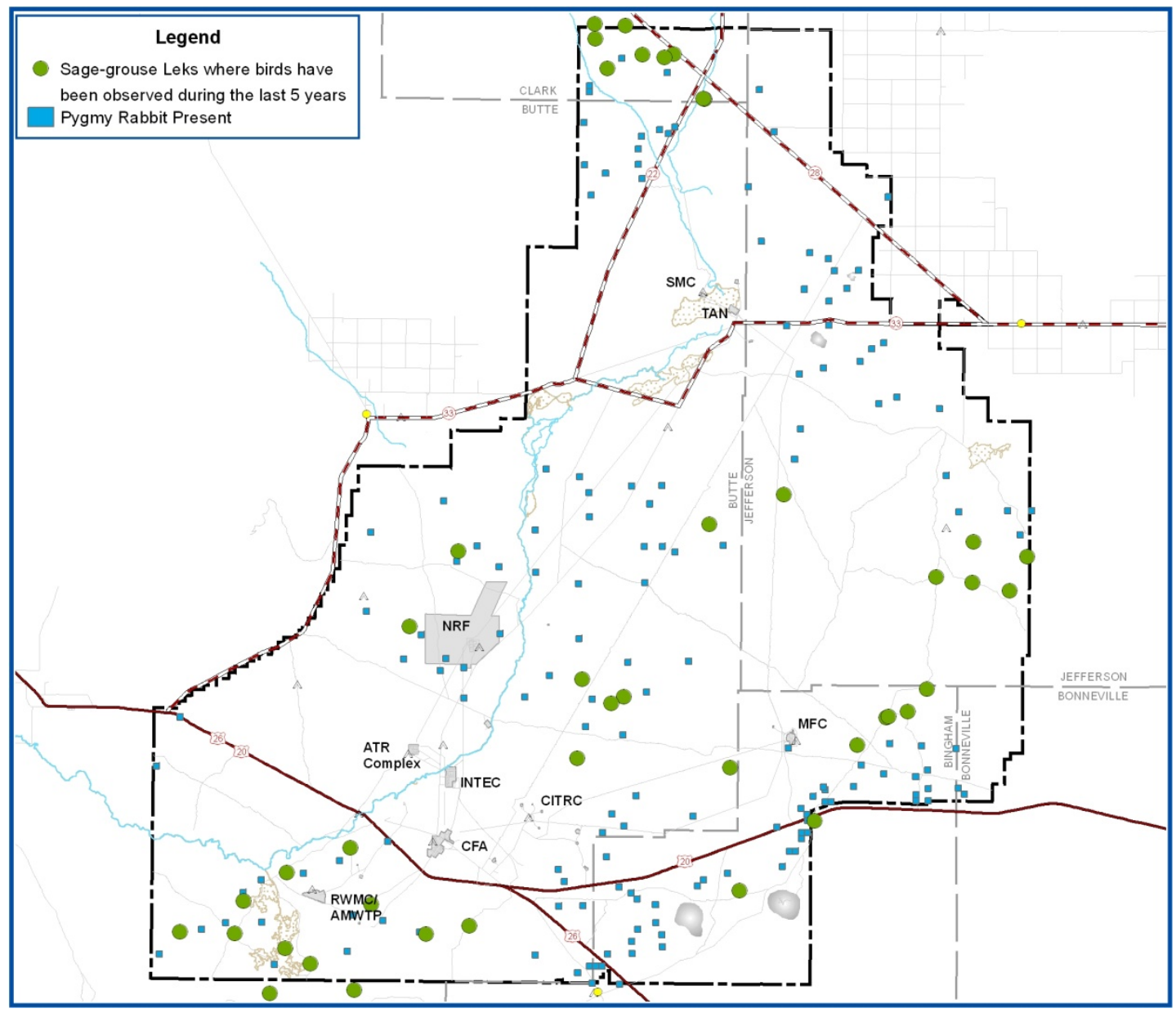

Figure 11. Ecological resources.

\subsubsection{Cultural Areas}

DOE recognizes the importance of cultural resources to its stakeholders and the importance of preserving those resources for present and future generations (Figure 12). Therefore, DOE will comply with legal mandates that require consideration of cultural resources. In 1975, DOE designated INL a national environmental research park, understanding the ecological diversity and research potential of the large and relatively undisturbed land area included within its boundaries. In 1997, a name change from 
Idaho National Engineering Laboratory to the Idaho National Engineering and Environmental Laboratory reflected increasing emphasis on environmental restoration and stewardship. In 1999, the U.S. Secretary of Energy designated a large portion of the Idaho National Engineering and Environmental Laboratory as a "sagebrush-steppe ecosystem reserve," recognizing its valuable and virtually pristine natural resources. Then, in February 2005, with the separation of the national laboratory and environmental restoration missions into two separate contracts, the Idaho National Engineering and Environmental Laboratory was renamed INL, its current designation.

The list of stakeholders and potential stakeholders is as varied as the resources themselves, including diverse groups such as local historical societies, museum associations, Oregon Trail enthusiasts, INL retirees, historical and scientific researchers, American Indian tribes, and the general public. These diverse stakeholders are involved at appropriate levels and times, including during an annual meeting to discuss recent and future activities regarding INL cultural resource management.

In general, all cultural resource reviews for archaeological resources begin with an exchange of information between the INL project manager and the INL Cultural Resource Management Office to identify a potential area(s) that may be affected. Once this area(s) is defined and the proposed activities within it are clearly understood, the Cultural Resource Management Office conducts an archive and literature review to determine the extent and results of any previous archaeological investigations within the area(s).

For each undertaking, DOE will consider potential effects on all types of cultural resources and will consult stakeholders accordingly. If it is determined that a particular undertaking will not affect resources and that no adverse effects will occur, documentation of negative findings or avoidance or protective measures will be maintained in the INL Cultural Resource Management Office archives.

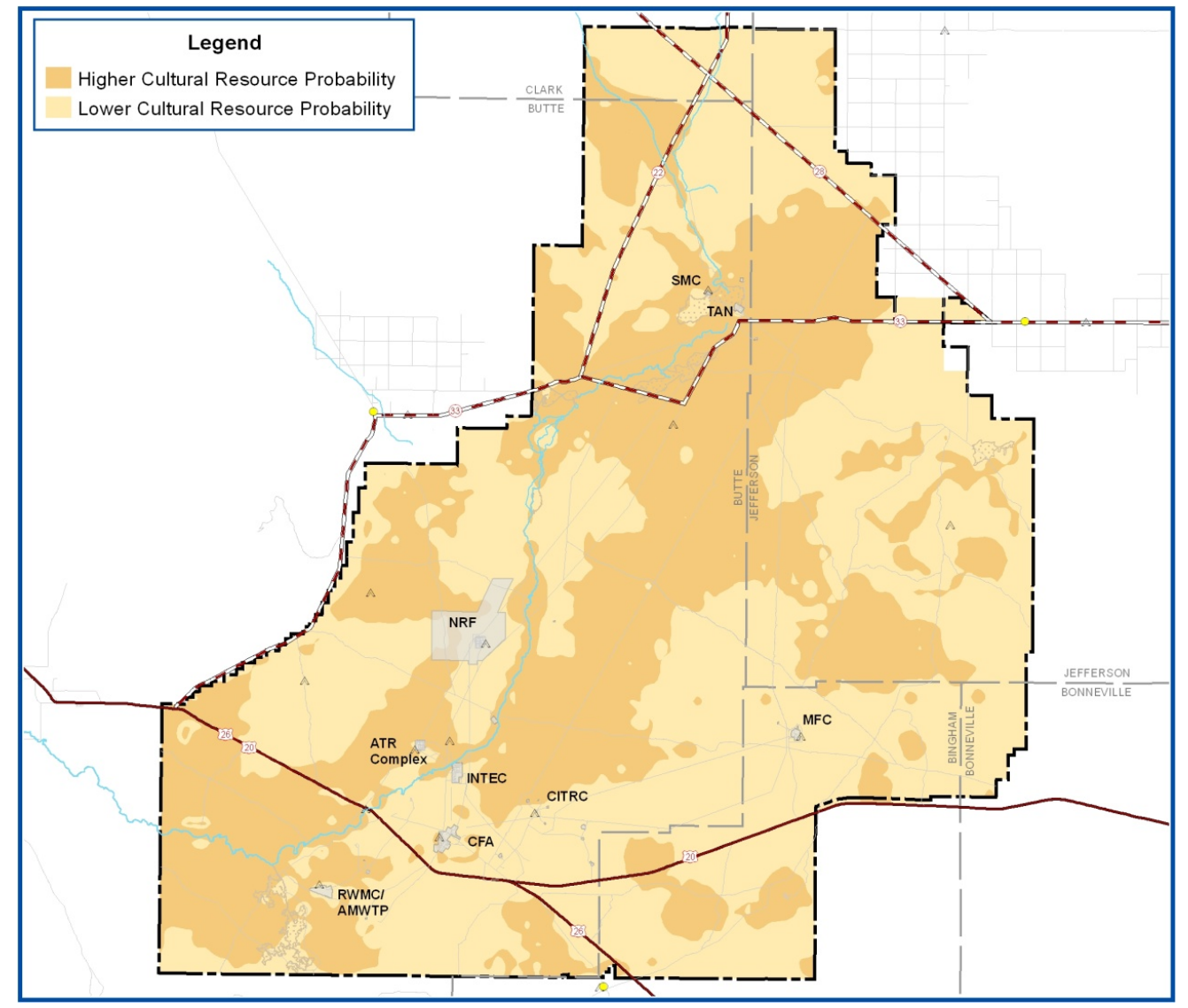

Figure 12. Cultural resources. 


\subsubsection{UXO/Firing Ranges}

The Live Fire Range Complex is located at CFA and a separate Live Fire Range is located at MFC (Figure 13). The principal purpose of the live fire ranges, which are operated by the INL Safeguards and Security Protective Force Training Department, is to provide firearms and tactical training/qualification requirements identified for Protective Force personnel. Use of these live fire ranges decreases the risks that are inherent in employing armed personnel. The live fire ranges also may be used by other DOE and DOE-contractor personnel and by other federal, state, and local law enforcement and military personnel for training, testing, qualification, and competition. Additionally, other approved organizations within the operating contractor use the live fire ranges to conduct testing and evaluation of different products and equipment and to provide training.

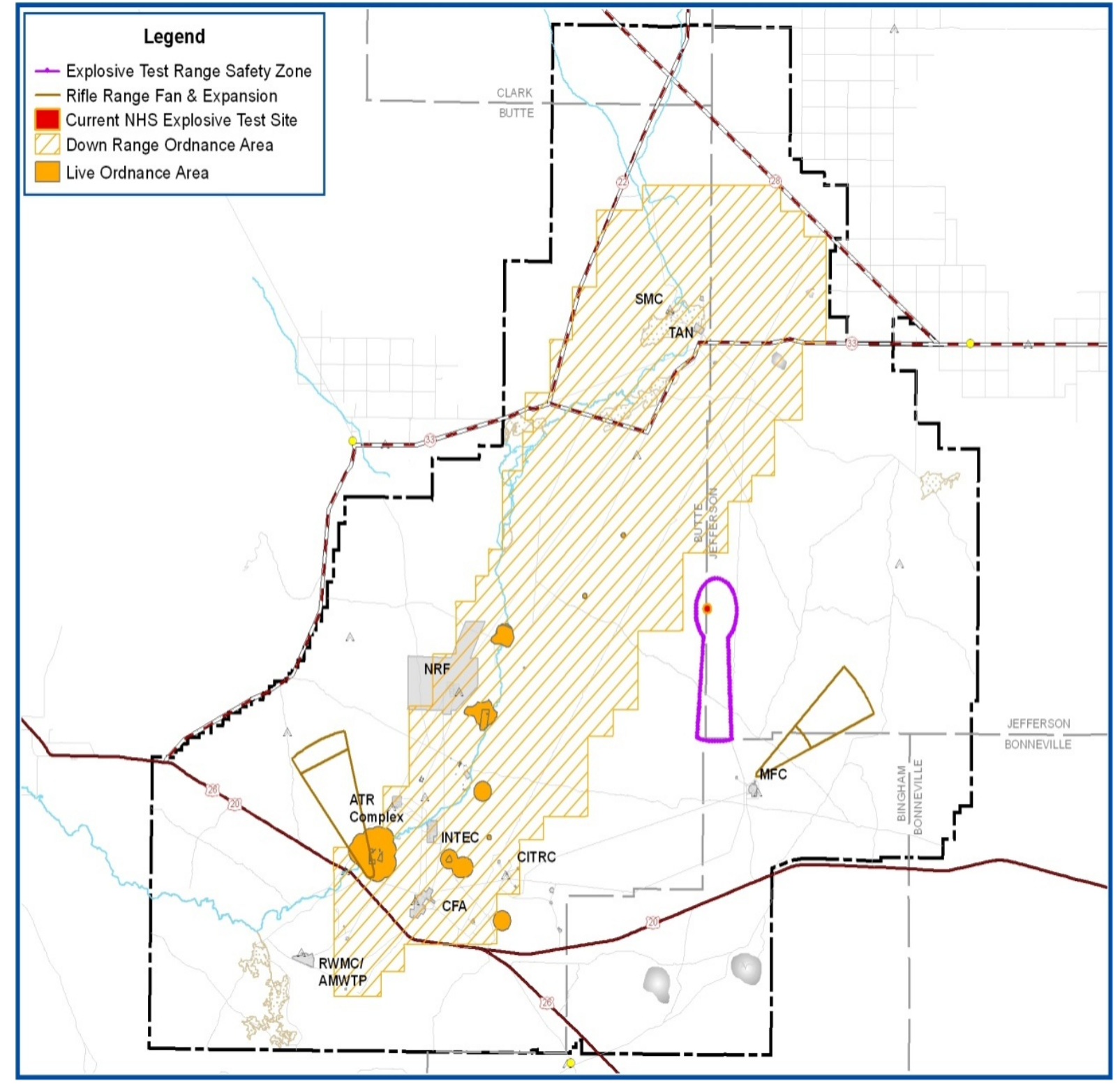

Figure 13. UXO/firing ranges. 
3.4.4.1.1 Central Facilities Area Live Fire Range Complex. Any weapon with a range of 10,000 yards or less may be fired on the range. At the CFA Live Fire Range Complex, an agreement with the Bureau of Land Management, Livestock Grazers, and INL stipulates weapons that exceed 8,500 yards will not be fired during the dates specified in the agreement unless there are controls in place to prevent the weapon from achieving a trajectory that would exceed 8,500 yards.

3.4.4.1.2 Materials and Fuels Complex Live Fire Range. The MFC Live Fire Range may support activities similar to the CFA Live Fire Range Complex. Consideration is given to the safety of both the live fire range users and others. The MFC Live Fire Range was designed to safely accommodate any firearm that does not have a maximum range exceeding 10,000 yard, or which does not fire high explosive projectiles. At the MFC Live Fire Range an agreement with the Bureau of Land Management, livestock grazers, and INL, stipulates that weapons that exceed 4,500 yards will not be fired during the dates specified in the agreement unless there are controls in place to prevent the weapon from achieving a trajectory that would exceed 4,500 yards.

A large area surrounding the MFC Live Fire Range has been defined as a surface danger zone and is posted with warning signs. The surface danger zone extends 10,000 yards down range from the firing line.

\subsubsection{Hunting/Grazing Areas}

A total of 219 resident and seasonal vertebrate species live on or frequent the INL Site each day (Arthur and Lom 1984; Reynolds et al. 1986). Birds constitute the largest single class of wildlife in this census, although many of the birds are migratory. Small mammals are the most common year-round residents. The most abundant big game animal residing on the INL Site is the pronghorn (Antilocapra americana). It is estimated that up to $40 \%$ of the pronghorn population of Idaho (and many from Montana) use the INL Site area during the winter months (Hoskinson and Tester 1980).

Deer and elk also are occasionally observed at the INL Site. Other big game animals, such as bison, no longer inhabit the area; however, Bison Rockshelter, Veratic Rockshelter, Owl Cave, and Wilson Butte Cave contain bison remains with associated cultural materials. Test excavations at a small prehistoric site near CITRC also indicate that bison were once hunted within INL boundaries (Ringe 1988).

INL has established the following 10 grazing allotments within its boundaries, for a total of 648,074 acres (Figure 14 shows these grazing allotments and hunting areas):

- $\quad$ Big Butte with 48,741 acres

- Cedar Point with 1,384 acres

- Deadman with 58,433 acres

- Howe Peak with 35,526 acres

- Mahogany Butte with 56,644 acres

- Quaking Aspen with 81,405 acres

- Reno Point with 2,073 acres

- $\quad$ Sinks with 30,606 acres

- Twin Buttes with 317,829 acres

- Wigwam Butte with 15,433 acres. 


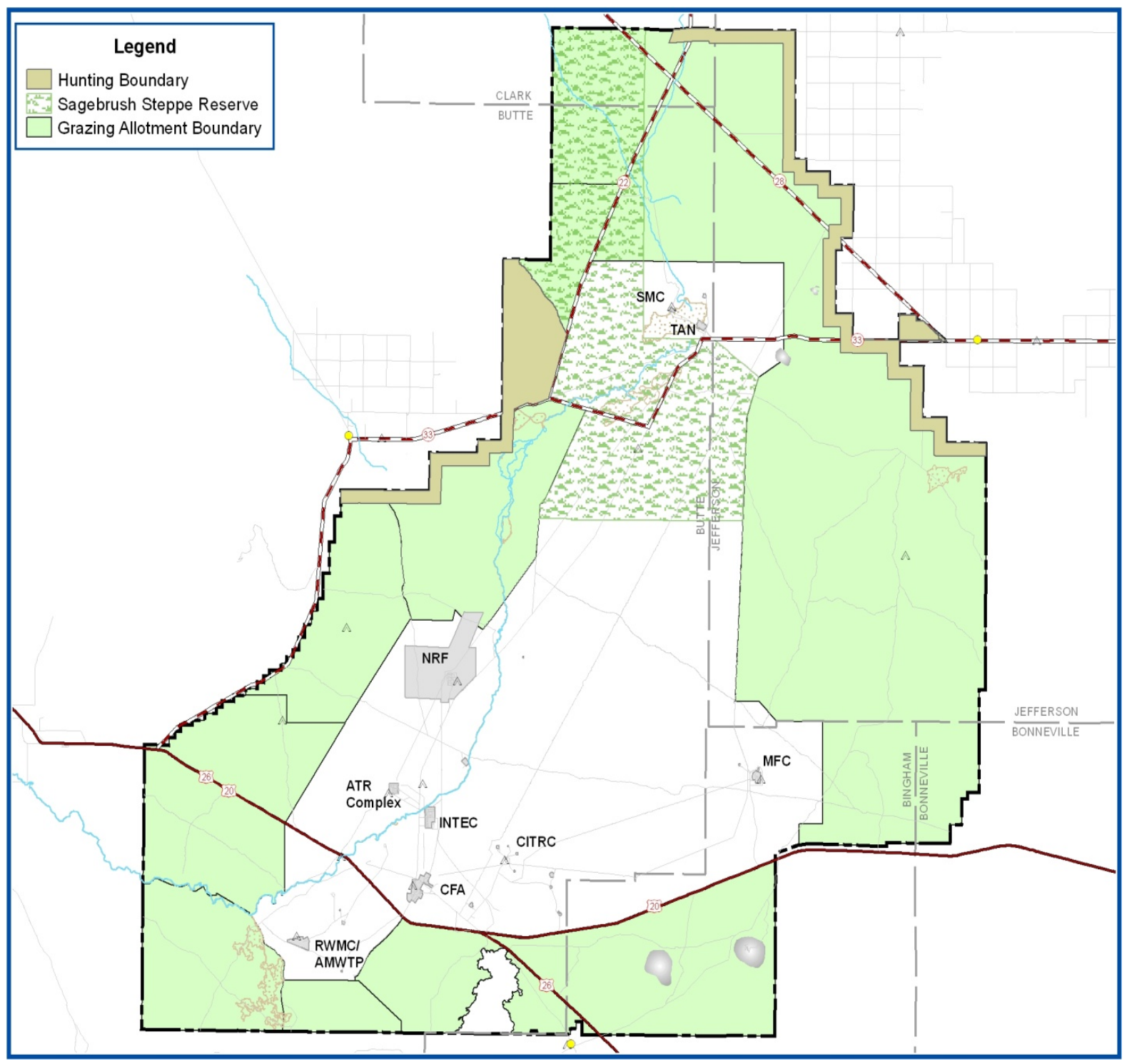

Figure 14. Hunting and grazing areas.

\subsection{Highway and Power Line Rights-of-Way and Easements}

In addition to restricted and potential constraint areas, another aspect to be evaluated is the existing highway and power line rights-of-way and easements. State Highways 20, 22, 26, 28, and 33 run across the INL Site. The State of Idaho Department of Transportation controls the rights-of-way and easements. Easements are typically 200 to $250 \mathrm{ft}$ on either side of the highway. A request to use a state right-ofway/easement is done via a use-permit application. Each permit application goes through an evaluation process and the state notifies INL. Highways 22, 26, and 33 are considered connecting roads and could be evaluated differently than Highways 20 and 28.

Utah Power/Rocky Mountain Power/PacifiCorp hold the right-of-way and easement for the 230-kV power line running north-south through the INL Site. Figure 15 shows the highway and power line rights-of-way/easements. 


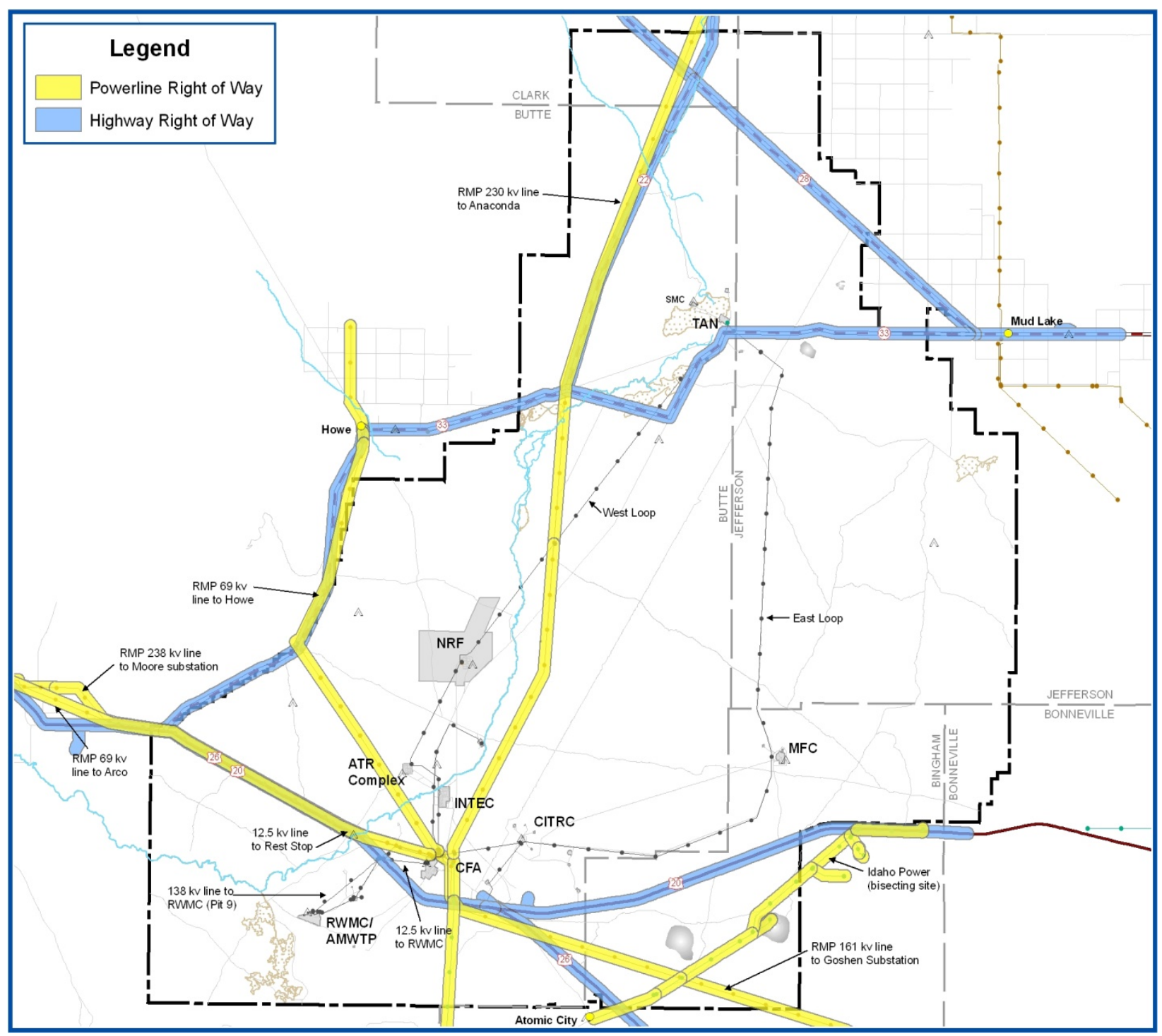

Figure 15. Highway and power line rights-of-way and easements.

\section{COMPREHENSIVE UTILITY CORRIDOR EVALUATION PROCESS}

Identification of INL Site features and the ability to geographically depict these features is critical the evaluation process. Previous sections geospatially detailed specific INL information and provided maps to illustrate that information as an individual data layer. This section combines all data layers developed and described in the previous sections (Figure 16). The following conclusions were drawn from the information obtained:

- Most of the INL missions occur toward the center of the INL site

- INL's perimeter has the least impact on missions

- Only sections along the perimeter are viable for a corridor

- A maximum corridor width of $3 / 4$ mile is doable around the perimeter

- Restrictions should be placed on the corridor

- A significant amount of work remains to proceed from a strategy to implementation of a CUC. 


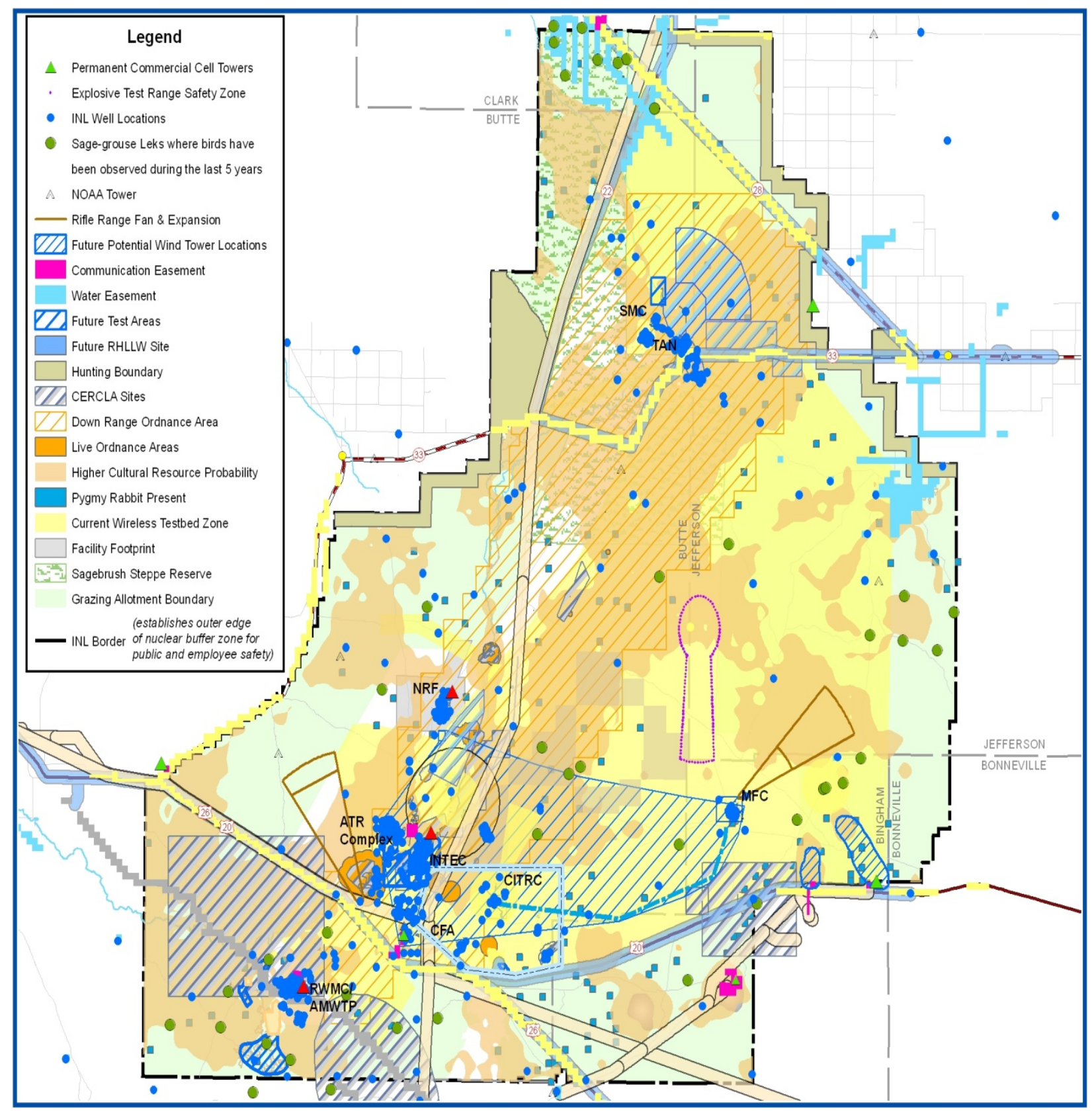

Figure 16. Comprehensive Idaho National Laboratory land-use map.

\section{OPTIONS FOR CONSIDERATION}

The evaluation process produced three options for consideration. Each of these options has some impact on INL missions and still requires extensive surveys and discussion to ensure economic viability and that operations and maintenance policies are thoroughly understood and in place. Figures 17 through 19 illustrate the three options that DOE can consider. 


\subsection{Option 1: Corridor around the Perimeter of the Idaho National Laboratory}

The area with the least impact on INL missions is around the perimeter of the INL Site. Option 1 identifies this perimeter; however, it does not mean the entire perimeter is viable. Many places along the perimeter corridor cannot be used or are not economically viable. Specific evaluations are needed to determine viable locations with minimal impact to INL missions.

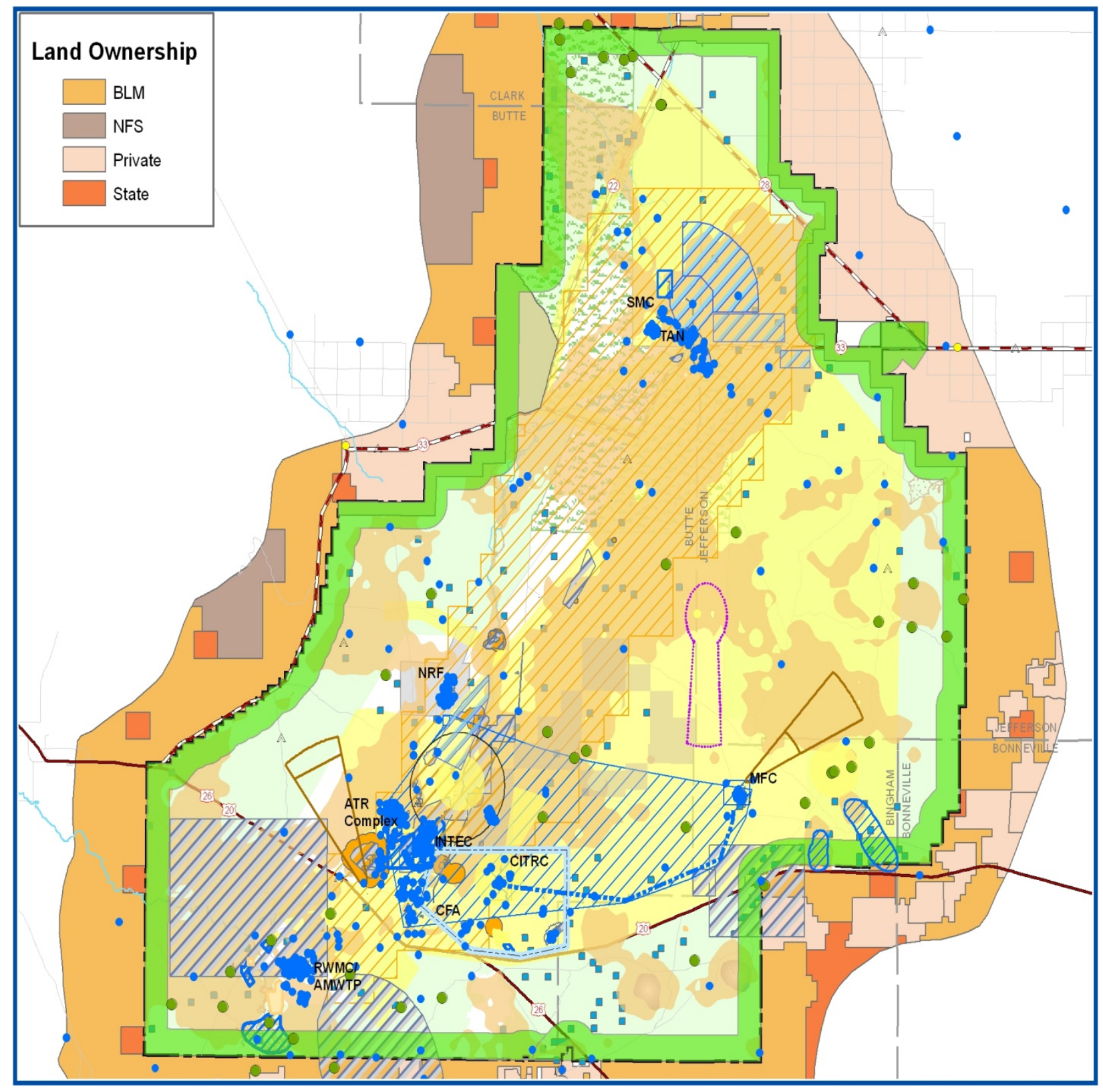

Figure 17. Option 1: Corridor around the Perimeter of the Idaho National Laboratory. 


\subsection{Option 2: Corridor along State Highways}

Option 2 identifies areas along existing highways that could be used as potential corridors. Discussions would have to take place with the state to use their easement as part of the corridor and mission impact would need to be evaluated.

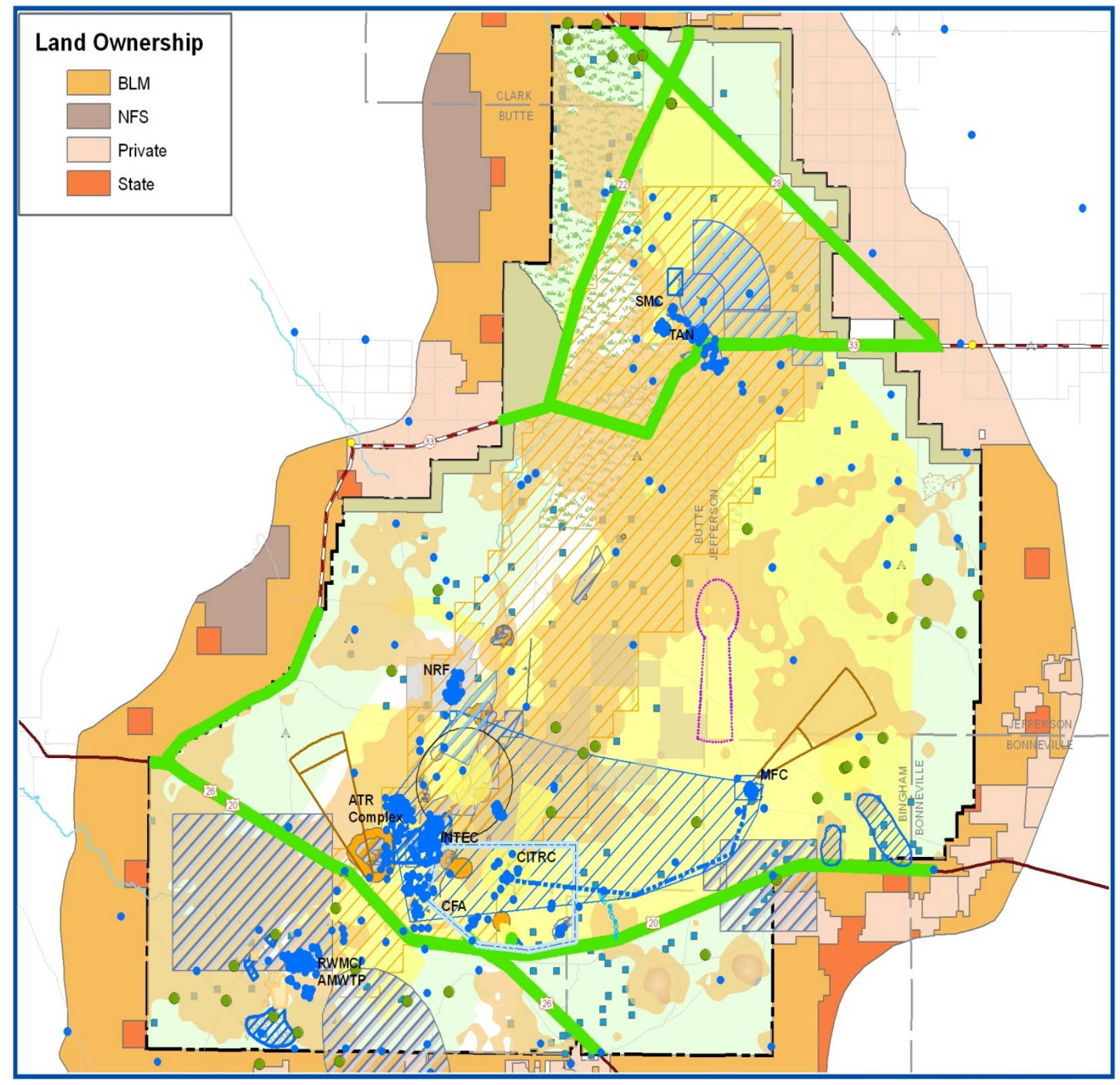

Figure 18. Option 2: Corridor along State Highways. 


\subsection{Option 3: Combination of Options}

Option 3 is a combination of Options 1 and 2. This option can provide the most flexibility to minimize impacts to INL missions. As with the other two options, discussions and agreements with the State of Idaho would be needed and any specific route would need to be thoroughly evaluated for impact, implementation, and operability beyond just a strategy.

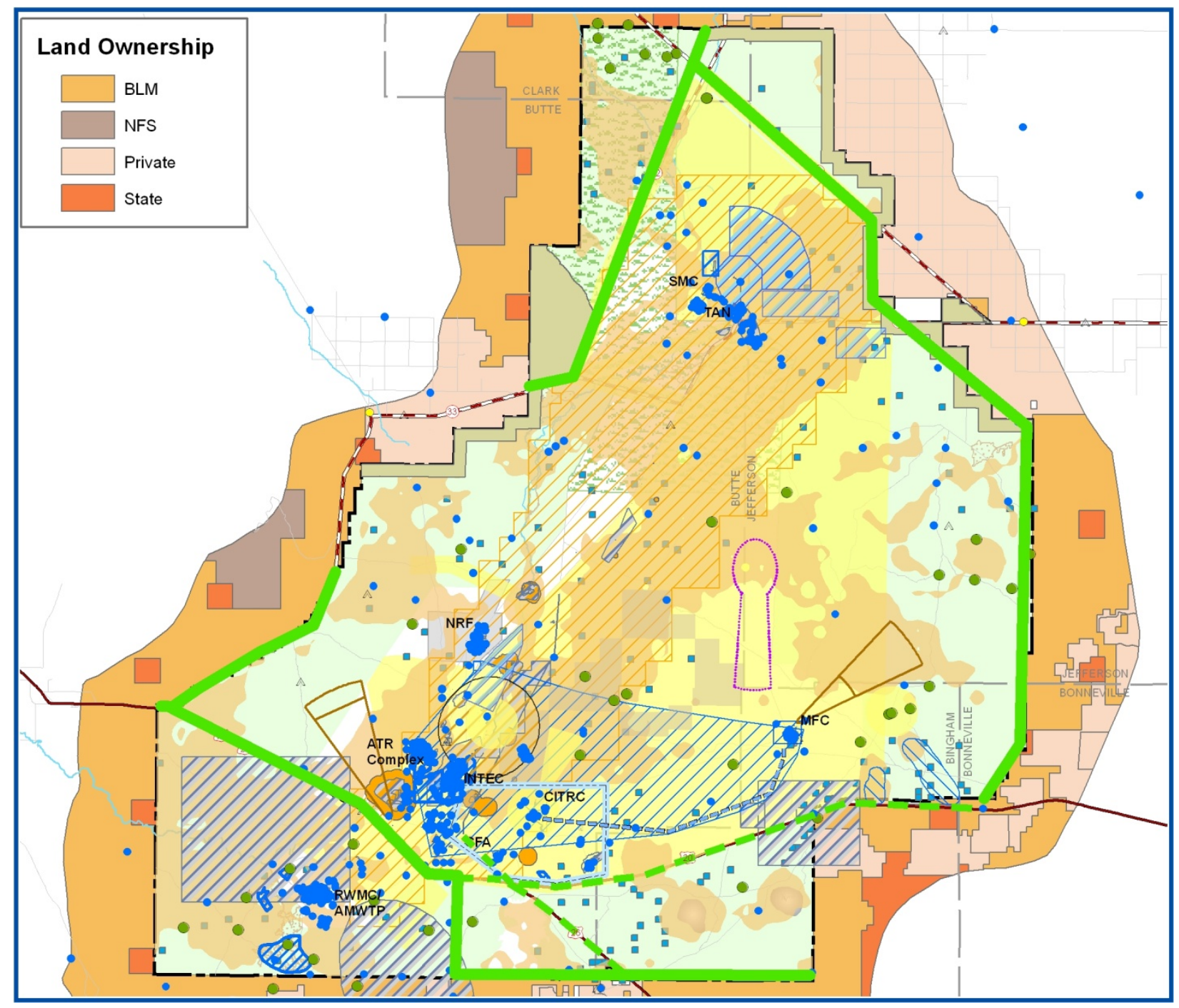

Figure 19. Option 3: Combination of Options.

\section{CONCLUSION}

INL has developed and implemented a process to identify and evaluate CUC options to consider. Any of the options will have some impact on INL missions; however, the options and the evaluation process behind the options provide a rationale and basis for decision making.

If a specific land use request is received by INL, the process by which that request would be evaluated is provided in this document. 


\section{REFERENCES}

Approved Resource Management Plan Amendments/Record of Decision for Designation of Energy Corridors on Bureau of Land Management-Administered Lands in the 11 Western States.

Arthur, J. R. and J. Lom, 1984, "Some Trichodinid Ciliates (Protozoa: Peritrichida) from Cuban Fishes, with Description of Trichodina Cubanensis n. sp. From the Skin of Cichlasoma Tetracantha," Trans. Am. Micros. Soc., 103: 172-184.

DOE Office of Environmental Management Closure Planning Guidance Document, dated June 1, 2004.

Energy Policy Act of 2005

Hoskinson, R. L. and J. R. Tester, 1980, "Migration Behavior of Pronghorn Antelope in Southeastern Idaho," J. Wildlife Management, 44: 132-144.

Reynolds, T. D., J. W. Connelly, D. K. Halford, and W. J. Arthur, 1986, "Vertebrate Fauna of the Idaho National Environmental Research Park," Great Basin Naturalist, 46(3): 513-527.

Ringe, B. L., 1988, "Test Excavation of Ten Sites along the Powerline between PBF and EBR-II, Idaho National Engineering Laboratory," Pocatello, ID: Swanson/Crabtree Anthropological Research Laboratory Reports of Investigations No. 88-6. 
Appendix A

\section{Expressions of Interest}




\section{Appendix A}

\section{Expressions of Interest}

AREVA, TransCanada, and NorthWestern Energy have each expressed interest in a CUC across the INL Site. The following figures provide their preferred corridor paths.

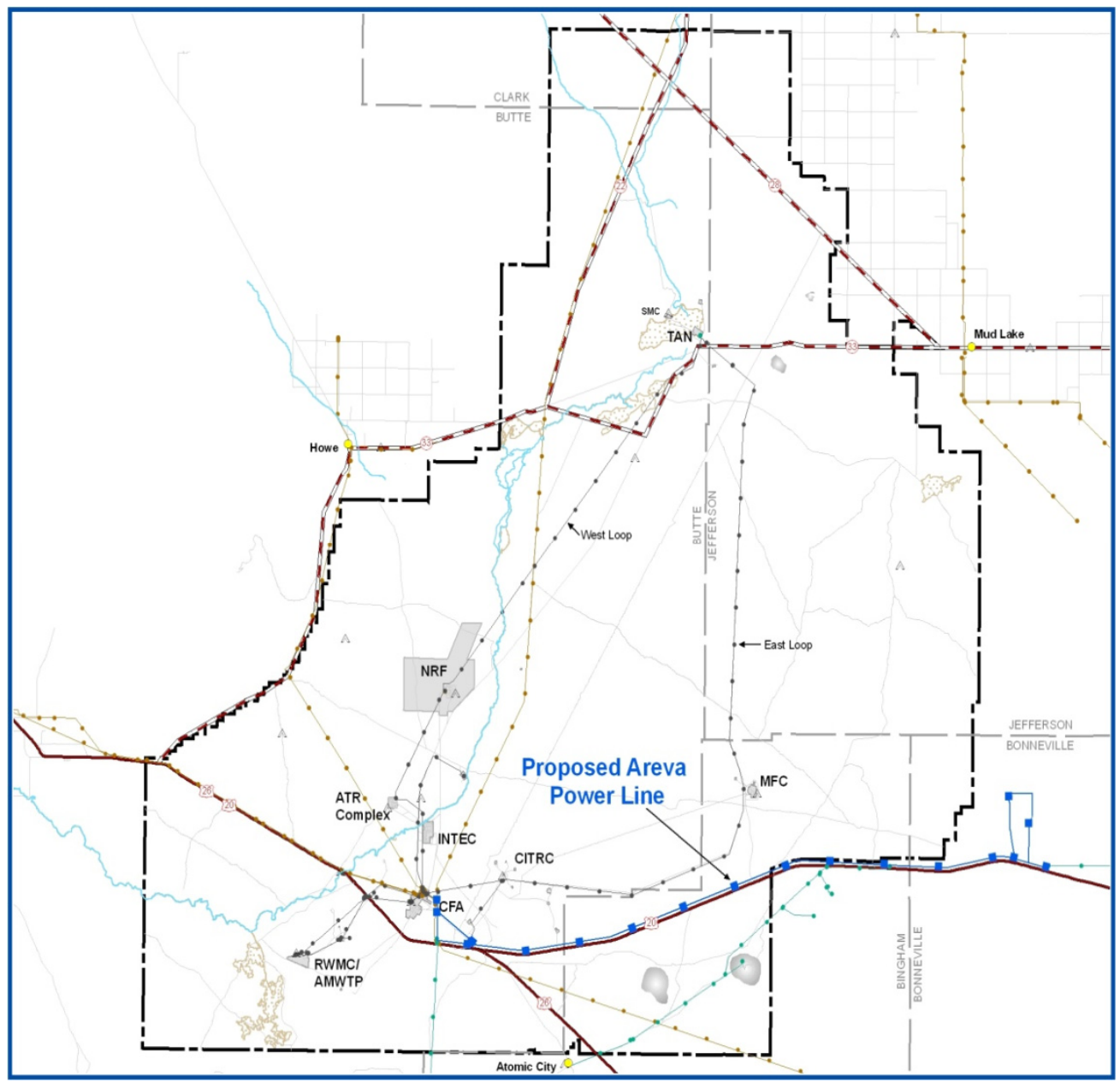

Figure A-1. AREVA proposed comprehensive utility corridor. 


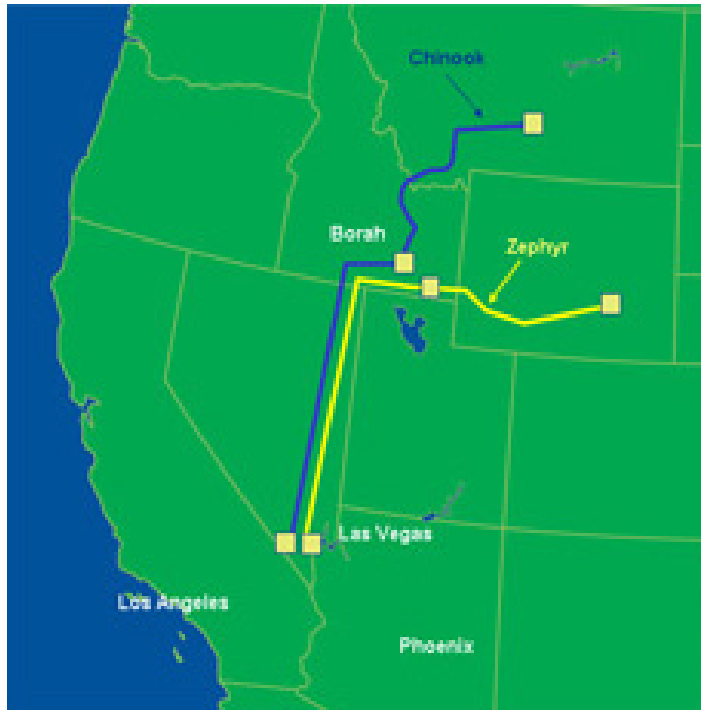

Figure A-2. TransCanada proposed comprehensive utility corridor. 


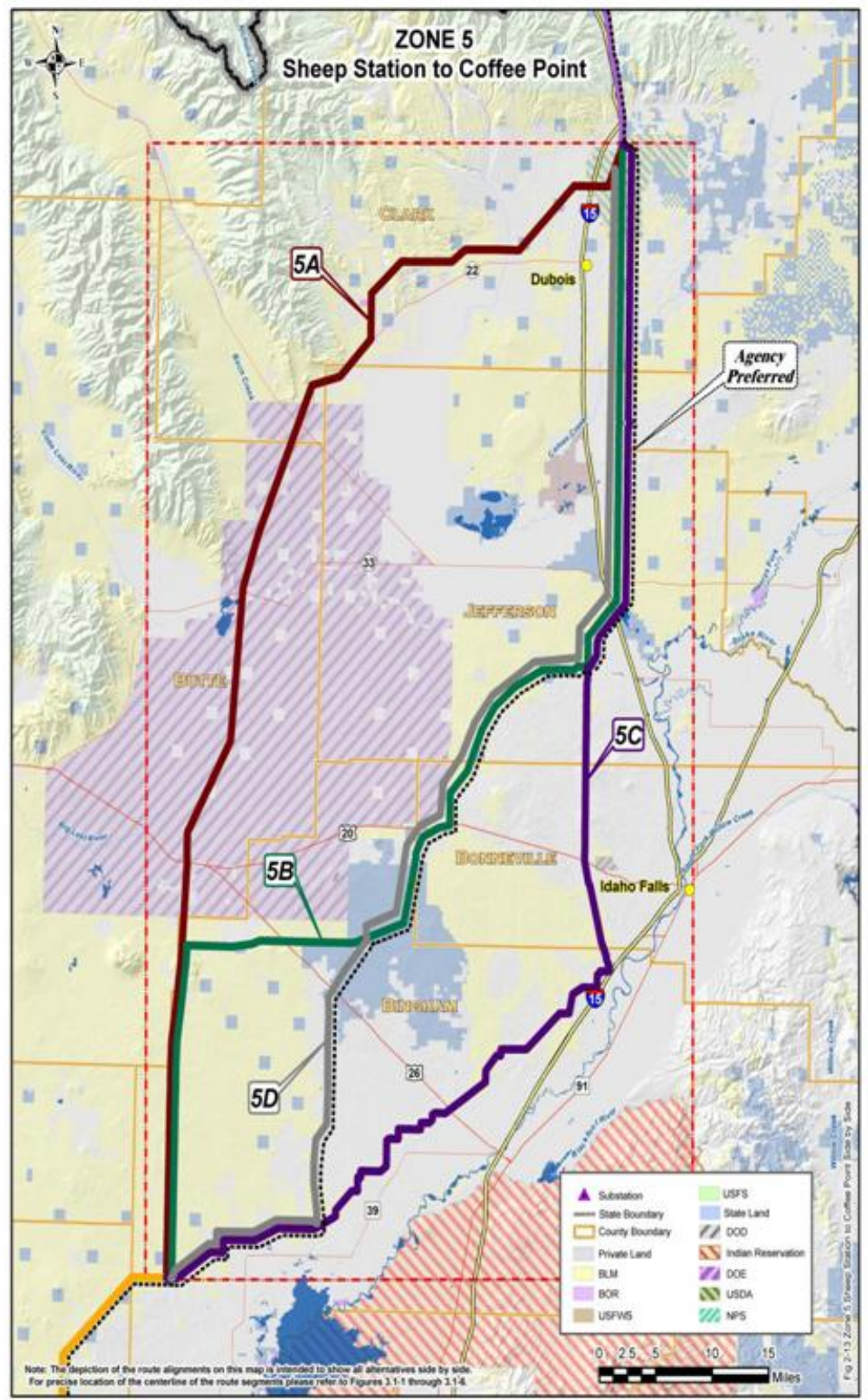

Figure A-3. Northwestern Energy proposed comprehensive utility corridor. 